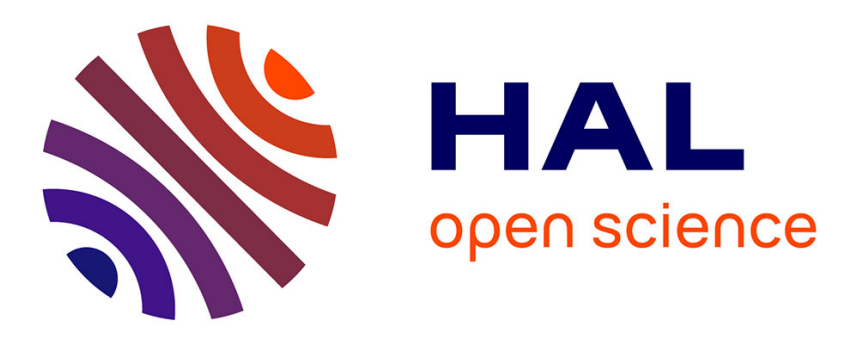

\title{
Copper(II) SBA-15: A reusable catalyst for azide-alkyne cycloaddition
}

Ibtissem Jlalia, Florian Gallier, Nancy Brodie-Linder, Jacques Uziel, Jacques Augé, Nadège Lubin-Germain

\section{- To cite this version:}

Ibtissem Jlalia, Florian Gallier, Nancy Brodie-Linder, Jacques Uziel, Jacques Augé, et al.. Copper(II) SBA-15: A reusable catalyst for azide-alkyne cycloaddition. Journal of Molecular Catalysis A: Chemical, 2014, 393, pp.56-61. 10.1016/j.molcata.2014.06.003 . hal-03553460

\author{
HAL Id: hal-03553460 \\ https://hal.science/hal-03553460
}

Submitted on 2 Feb 2022

HAL is a multi-disciplinary open access archive for the deposit and dissemination of scientific research documents, whether they are published or not. The documents may come from teaching and research institutions in France or abroad, or from public or private research centers.
L'archive ouverte pluridisciplinaire HAL, est destinée au dépôt et à la diffusion de documents scientifiques de niveau recherche, publiés ou non, émanant des établissements d'enseignement et de recherche français ou étrangers, des laboratoires publics ou privés. 


\section{Elsevier Editorial System(tm) for Journal of Molecular Catalysis A: Chemical}

Manuscript Draft

Manuscript Number:

Title: Copper(II) SBA-15: a reusable catalyst for azide-alkyne cycloaddition

Article Type: Research Paper

Section/Category: Heterogeneous catalysis

Keywords: Click Chemistry; Mesoporous materials; Cycloaddition, Recycling, Heterogeneous Catalysis, Copper(II).

Corresponding Author: Prof. Nadège Lubin-Germain,

Corresponding Author's Institution: University of Cergy-Pontoise

First Author: Nadège Lubin-Germain

Order of Authors: Nadège Lubin-Germain; Jacques Uziel, Dr; Jacques Augé, Prof.; Nancy Brodie-Linder, Dr; Florian Gallier, Dr; Ibtissem Jlalia, Dr

Abstract: The azide-alkyne cycloaddition reaction was investigated under catalytic conditions involving a copper (II) loaded silica based mesoporous material. Cu(II) SBA-15 demonstrated a high catalytic effect in 1,4-triazoles synthesis in organic. No additives such as a base or a reductant are required. Quantitative yields were obtained and a mere filtration of the mesoporous material which retains copper (II) allows the recovery of the catalyst. In addition, up to 5 times recycling of the catalyst was achieved without loss of the activity affording 1,4-triazoles in a yield up to $98 \%$.

Suggested Reviewers: Udo Kragl PhD

Prof, Institut für Chemie, Universität Rostock

udo.kragl@uni-rostock.de

Andrea Goti PhD

Prof, Dipartimento di Chimica "Ugo Schiff", University of Florence

andrea.goti@unifi.it

Rodrigo Octavio Mendonça Alves de Souza PhD

Prof, Instituto de Química. , Federal University of Rio de Janeiro

souzarod21@yahoo.com.br

Christian David PhD

Prof, Chimie ParisTech

christian-girard@chimie-paristech.fr 
Pr Nadège Lubin-Germain

Laboratoire SOSCO

5 mail Gay-Lussac

Neuville sur Oise

95031 Cergy-Pontoise Cedex France

Tel. + 33134257054

Fax. +331342570 71

Email.nadege.lubin-germain@u-cergy.fr
Cergy-Pontoise, March $21^{\text {th }} 2013$

Journal of molecular Catalysis A Editor

Please find enclosed a manuscript entitled "Copper(II) SBA-15: a reusable catalyst for azide-alkyne cycloaddition". This work concerns the use of supported Copper(II) on a mesoporous material, as catalyst in the 1,3 dipolar cycloaddition. We demonstrated the efficiency of the catalyst towards various alkynes and azides and its reusability without loss of reactivity.

We also showed that, from a mechanistic point of view, Copper(II) seems acting as Copper(I), with the formation of a metal-carbon bond as usually described in this reaction and not as Lewis acid. This is sustained by different experiments such as deuteration of the alkyne, oxidative conditions for the reaction and kinetic studies. It is noteworthy that is the first time that this kind of reactivity is proposed for Copper(II).

Moreover, I declare that all authors are aware of the submission and agree to its publication. The submission is original, and is not under consideration for publication elsewhere.

Hoping that this work could be published in J. Mol Cat. A,

Sincerely yours,

Pr Nadège Lubin-Germain

Contact details of the reviwers:

Prof. Dr. Udo Kragl

Universität Rostock

Institut für Chemie

Abteilung Analytische und Technische Chemie

Albert-Einstein-Str. 3a

D-18059 Rostock

49(0)381-498-6450

udo.kragl@uni-rostock.de

\section{Prof. Andrea Goti}

Università di Firenze

Dipartimento di Chimica "Ugo Schiff"

Via della Lastruccia, 3-13

50019 SESTO FIORENTINO 
andrea.goti@unifi.it

390554573505

Prof. Rodrigo Octavio Mendonça Alves de Souza

Universidade Federal do Rio de Janeiro, Instituto de Química.

CT,Bloco A, Ilha do Fundão

Ilha do fundão

21941-909 - Rio de Janeiro, RJ - Brasil

(21) 25627248

souzarod21@yahoo.com.br

Dr Christian Girard

Chimie ParisTech

5 rue Pierre et Marie Curie

75005 Paris

33144276748

christian-girard@chimie-paristech.fr 
Copper(II) SBA-15: a reusable catalyst for azide-alkyne cycloaddition

Ibtissem Jlalia, ${ }^{\mathrm{a}}$ Florian Gallier, ${ }^{\mathrm{b}}$ Nancy

Brodie-Linder,,${ }^{\text {bc, }}{ }^{*}$ Jacques Uziel, ${ }^{\mathrm{b}}$ Jacques

$\mathrm{R}=\mathrm{H}$

$+$

$R^{\prime}-\stackrel{\ominus}{N}-\stackrel{\oplus}{N} \equiv N$

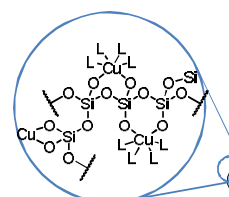

$\longrightarrow$

Augé, ${ }^{\mathrm{b}}$ and Nadège Lubin-Germain,,

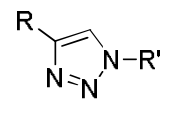

1,4 onl 
${ }^{*}$ Highlights (for review)

\section{Highlights}

Copper(II) catalyses the Alkyne-Alcyne cycloaddition reaction

$\mathrm{Cu}-\mathrm{SBA}-15$ operates by a Copper(I)-like mechanism leading complete regioselectivity

The catalyst can be reused without loss of yield and regioselectivity 


\section{Copper(II) SBA-15: a reusable catalyst for azide-alkyne cycloaddition}

Ibtissem Jlalia, ${ }^{\mathrm{a}}$ Florian Gallier, ${ }^{\mathrm{b}}$ Nancy Brodie-Linder, ${ }^{\mathrm{b}, \mathrm{,}}{ }^{*}$ Jacques Uziel, ${ }^{\mathrm{b}}$ Jacques Augé, ${ }^{\mathrm{b}}$ and Nadège Lubin-Germain,

${ }^{a}$ Laboratoire des Substances Naturelles, INRAP-Pôle Technologique, Sidi Thabet 2020, Tunisia

${ }^{\mathrm{b}}$ Laboratoire de Synthèse Organique Sélective et Chimie bioOrganique, EA 4505, University of Cergy-Pontoise, F-95000 Cergy-Pontoise cedex, France

cLaboratoire Léon Brillouin, CEA Saclay, Bât. 563, F-91191 Gif-sur-Yvette, France

Corresponding author: Phone: (+33) 1-34-25-70-54; fax: (+33) 1-34-25-73-78; e-mail: nadege.lubin-germain@u-cergy.fr

\footnotetext{
Abstract.

The azide-alkyne cycloaddition reaction was investigated under catalytic conditions involving a copper (II) loaded silica based mesoporous material. Cu(II) SBA-15 demonstrated a high catalytic effect in 1,4-triazoles synthesis in organic. No additives such as a base or a reductant are required. Quantitative yields were obtained and a mere filtration of the mesoporous material which retains copper (II) allows the recovery of the catalyst. In addition, up to 5 times recycling of the catalyst was achieved without loss of the activity affording 1,4-triazoles in a yield up to $98 \%$.
} 
Keywords: Click Chemistry; Mesoporous materials; Cycloaddition, Recycling, Heterogeneous Catalysis, Copper(II).

\section{Introduction}

The copper-catalyzed azide-alkyne cycloaddition (CuAAC) is the landmark reaction in click chemistry and originates from the pioneering works of Sharpless et al. ${ }^{1}$ and Meldal et $a l .{ }^{2}$ Copper (I) catalysis accelerates dramatically the Huisgen 1,3-dipolar reaction and leads to a high regioselectivity in favor of the 1,4-isomer of the triazole product. The copper (I) catalysts generally originate from copper (I) salts in presence of a base and/or a ligand, in situ reduction of copper (II) salts usually by ascorbate, and/or a mixture of copper (0) and copper (II) species. ${ }^{3}$ Heterogeneous copper (I) sources have also been described as they present a great advantage concerning catalyst removal, recovery and recycling. $\mathrm{Cu}(\mathrm{I})$ salts have been supported on ionic resins, ${ }^{4}$ various polymeric backbones, ${ }^{5}$ silica, ${ }^{6}$ ionic liquids, ${ }^{7}$ montmorillonite, ${ }^{8}$ zeolites, ${ }^{9}$ or biopolymers. ${ }^{10}$ The main drawback is that such heterogeneous catalysts frequently suffer from the thermodynamic instability of $\mathrm{Cu}(\mathrm{I})$ which is prone to oxidation or disproportionation. Therefore, $\mathrm{Cu}(\mathrm{II})$ has recently been immobilized on alumina, ${ }^{11}$ silica, ${ }^{12}$ anatase,${ }^{13}$ various polymeric backbones,${ }^{14}$ heteropolyacids,${ }^{15}$ minerals,${ }^{16}$ or biooligomers ${ }^{17}$ with or without the presence of a sacrificial reducing agent.

With respect to our work, we have already been concerned with controlling the regioselectivity of the reaction in microreactors such as micelles. ${ }^{18}$ Herein we have explored the usefulness of mesoporous material and the potential role of the pores in the catalysis of the process. Indeed copper loaded on silica type materials as MCM-41 and SBA-15 have been shown to be very useful in selective catalytic experiments. ${ }^{19}$ 


\section{Experimental Methods}

\subsection{Characterization of the mesoporous $C u(I I) S B A-15$}

The SBA-15 material was prepared according to a well-established procedure. ${ }^{1}$ This mesoporous silica $(50 \mathrm{mg}$ ) was then suspended for $10 \mathrm{~min}$ at room temperature in $20 \mathrm{~mL}$ of a $5 \cdot 10^{-2} \mathrm{~mol} / \mathrm{L}$ aqueous solution of $\mathrm{Cu}\left(\mathrm{NO}_{3}\right)_{2} \cdot 3 \mathrm{H}_{2} \mathrm{O}$ containing a particular amount of a solution of $28 \%(w / w) \mathrm{NH}_{4} \mathrm{OH}$ in order to obtain $\mathrm{pH} 10.5$. $^{2}$ The material was then filtered, washed profusely with water to ensure the removal of all free $\mathrm{Cu}(\mathrm{II})$ ions and dried in an oven at $60^{\circ} \mathrm{C}$ for $4 \mathrm{~h}$ to give a bluish solid. Control of the time and $\mathrm{pH}$ of impregnation is crucial for the copper loading.

The copper uptake was then determined by UV-visible spectroscopy. A sample of $\mathrm{Cu}(\mathrm{II}) \mathrm{SBA}-15(10 \mathrm{mg})$ is suspended in $5 \mathrm{~mL} 2 \%(\mathrm{w} / \mathrm{w})$ aqueous $\mathrm{HNO}_{3}$ and stirred for 15 minutes at room temperature, vigorously in order to ensure the best homogeneity possible in solution and filtered. UV absorbance of the solution was measured and the copper content was calculated with the standard calibration curve.

Each batch of $\mathrm{Cu}(\mathrm{II}) \mathrm{SBA}-15$ is further characterized by IR spectroscopy and $\mathrm{N}_{2}-$ adsorption measurement. The following table gives the detailed values of Pore volume and Pore diameter as well as the BET Surface area for the freshly prepared $\mathrm{Cu}$ (II) SBA-15, the $\mathrm{Cu}(\mathrm{II}) \mathrm{SBA}-15$ after several runs (simply filtered after the last run) and the $\mathrm{Cu}(\mathrm{II}) \mathrm{SBA}-15$ thoroughly rinsed after the last run.

\subsection{General Procedure for Cu(II) SBA-15 Azide- Alkyne Cycloaddition}

\footnotetext{
${ }^{1}$ N. Brodie-Linder, G. Dosseh, C. Alba-Simionesco, F. Audonnet, M. Impéror-Clerc, Mater. Chem. Phys. 2008, 108, 73-81.

${ }^{2}$ N. Brodie-Linder, R. Besse, F. Audonnet, S. LeCaer, J. Deschamps, M. Impéror-Clerc, C. Alba-Simionesco, Micropor. Mesopor. Mater. 2010, 132, 518-525.
} 
Alkyne $(0.5 \mathrm{mmol})$, azide $(0.55 \mathrm{mmol})$ and $\mathrm{Cu}(\mathrm{II}) \mathrm{SBA}-15(25 \mathrm{mg}, 8 \mathrm{~mol} \% \mathrm{Cu})$ were stirred in dichloromethane $(2 \mathrm{~mL})$ overnight. The mixture was filtered and the solid was washed twice with $2 \mathrm{~mL}$ of dichloromethane. The filtrate was concentrated by evaporation under vacuum. Excess of azide can be removed after immobilization on a triphenylphosphine resin. In the case of highly polar substrates, the solid was washed twice with $2 \mathrm{~mL}$ of acetonitrile.

\subsection{General procedure for catalyst recycling}

To a screw-capped vial were successively added ethyl propiolate $(50 \mu \mathrm{L} ; 0.49 \mathrm{mmol})$, benzyl azide (73.2 $\mathrm{mg} ; 1.15$ eq.), dichloromethane ( $2 \mathrm{~mL})$ and finally the $\mathrm{Cu}(\mathrm{II})-\mathrm{SBA} 15$ (25 $\mathrm{mg} ; 7.5 \% \mathrm{Cu}$ w/w $; 6 \mathrm{~mol} \%)$. The reaction was stirred overnight and the catalyst was recovered by filtration over a nylon membrane $\left(0.45 \mu \mathrm{m}\right.$, Millipore $\left.{ }^{\circledR}\right)$ and washed with dichloromethane $(2 \times 2 \mathrm{~mL})$. The combined organic solvent was evaporated under vacuo yielding the desired triazole $(97-110 \mathrm{mg} ; 87-97 \%)$. After the $5^{\text {th }}$ run we recovered $23.9 \mathrm{mg}$ of the catalyst (over the $25 \mathrm{mg}$ used for the $1^{\text {st }}$ reaction), hence a recovery of $93 \%$ over 5 runs (99\% average recovery per run).

\section{Results and Discussion}

\subsection{Catalysis}

One of us recently reported the conditions for the controlled $\mathrm{Cu}$ (II) loading in SBA-15 materials from 6 to $20 \% \mathrm{Cu}(\mathrm{w} / \mathrm{w}) .{ }^{20}$ It was shown that the amount of $\mathrm{Cu}(\mathrm{II})$ loaded on the SBA-15 surface could be controlled by a reaction in aqueous copper solutions at ambient temperature in 10 minutes. It was also shown that good copper dispersion over the surface was achieved. For the azide-alkyne cycloaddition reaction, we synthesized an SBA-15 material using the identical method given in ref. 20. The copper loaded SBA-15 material was 
prepared in an aqueous copper nitrate solution $\left(5.10^{-2} \mathrm{M}\right)$ at $\mathrm{pH} 10.5$. The $\mathrm{pH}$ was adjusted by the addition of an aqueous solution of $\mathrm{NH}_{4} \mathrm{OH}(28 \% \mathrm{w} / \mathrm{w})$. The SBA-15 copper loaded blue powder (Cu(II) SBA-15) was characterized by $\mathrm{N}_{2}$ adsorption analysis giving a pore size of 7.0 $\mathrm{nm}$, a surface area of $306 \mathrm{~m}^{2} \mathrm{~g}^{-1}$ and a pore volume of $0.483 \mathrm{~cm}^{3} \mathrm{~g}^{-1}$. The copper was extracted from the $\mathrm{Cu}(\mathrm{II}) \mathrm{SBA}-15$ material with a $2 \% \mathrm{HNO}_{3}$ aqueous solution which was analyzed by UV-visible spectroscopy giving a copper content at $10 \%(\mathrm{w} / \mathrm{w})$.

The cycloaddition between ethyl propiolate and benzyl azide was first investigated using an increasing amount of $\mathrm{Cu}(\mathrm{II}) \mathrm{SBA}-15$ in dichloromethane. The conversion into the 1,4disubstituted triazole was determined by ${ }^{1} \mathrm{H}-\mathrm{NMR}$ spectroscopy after 2 hours of reaction (Table 1). We were delighted to discover that a copper (II) catalyst could efficiently catalyze at room temperature such a reaction, without further addition of a reducing agent which would have allowed the existence of $\mathrm{Cu}(\mathrm{I})$ species. The reaction is totally regioselective as in the $\mathrm{Cu}(\mathrm{I})$ cycloaddition.

Table 1. Catalyst amount optimization

In order to demonstrate the scope of this catalysis, various alkynes and azides were tested using a moderate amount $(8 \mathrm{~mol} \%)$ of the catalyst (Table 2$)$. The reaction proceeded efficiently with ethyl propiolate (entries 1-5), 3,3-diethoxyprop-1-yne (entries 6-9) and 4bromobut-1-yne (entries 10-14). The isolated yields are particularly high, sometimes quantitative (entries 1, 3, 12), with benzyl azides.

Table 2. Scope and limitations of the catalyzed cycloaddition

When propargylamine was used, the reaction proceeded instantaneously but the triazole was recovered in very poor yield probably due to the amino complexation to copper (entry 20). This CuAAC rate acceleration by amino group complexation has already been 
observed. ${ }^{21}$ The same observation could be made concerning alcohol-containing reactants in a less important manner (entries 15-19).

Since no reaction was observed with octyne and 2,3,4,6-tetra- $O$-benzyl- $\beta$-Dglucopyranosylacetylene (entries 21 and 22), it is supposed that the catalysis was impeded in these two cases by the size of the molecules $(20 \AA)$ compared to that of the pores $(70 \AA)$ which contain the copper catalytic species. Such an effect of the importance of the size of the pores was not observed with $\mathrm{Cu}(\mathrm{I})$-zeolites which accept any substrate. ${ }^{9 \mathrm{~b}}$ Our observation opens the way to the possibility of tuning the size of the pores in concordance with the substrates. Concerning octyne, we can also take into account the hydrophilic character of the pores and we can postulate that the octyne preferred to remain outside in the organic phase.

\subsection{Recycling of the $\mathrm{Cu}(\mathrm{II}) \mathrm{SBA}-15$}

The reaction was tested on ethyl propiolate with benzylazide and we demonstrated that it proceeded with the same yield for at least five times (Figure 1). After each run, the catalyst can be almost quantitatively recovered by a mere filtration over a $0.45 \mu \mathrm{m}$ nylon membrane.

Figure 1. $\mathrm{Cu}(\mathrm{II}) \mathrm{SBA}-15$ reusability.

After the last catalytic cycle, a more thorough washing was performed and the material was analyzed in order to control the state of the catalytic surface. The IR spectra found in Figure 2 indicate that no build-up of organic materials on the surface is occurring. This is also corroborated by $\mathrm{N}_{2}$ volumetric adsorption analysis where only slight changes in the pore structure can be observed (see Supporting Information). In addition, the content of copper remained identical indicating that no leaching occurred.

Figure 2. IR spectra of $\mathrm{Cu}$ (II) SBA-15 materials before and after several catalytic cycles.

\subsection{Mechanistic studies}


To our knowledge, the first example of the use of $\mathrm{Cu}(\mathrm{II})$ as the reactive catalytic species in the Huisgen reaction was described in aqueous medium. ${ }^{22}$ Later on, a di-copper (II) substituted silicotungstate was shown to catalyze both the oxidative alkyne-alkyne homocoupling and the Huisgen reaction; the high yield in 1,2,3-triazoles in that reaction was proven to be due to the preformation of a $\mathrm{Cu}(\mathrm{I})$ acetylide. ${ }^{15 a}$ With $\mathrm{Cu}(\mathrm{OAc})_{2}$ as catalyst, a fast reaction occurred with organic azides capable of chelation-assisted copper coordination at the alkylated nitrogen position. $^{23}$

\subsection{Oxidation state of Copper}

In these cases, the authors suggest that $\mathrm{Cu}(\mathrm{II})$ undergoes reduction to $\mathrm{Cu}(\mathrm{I})$ via alcohol (solvent) oxidation and/or alkyne homocoupling; they gave experimental evidence of the formation of a mixed-valency dinuclear copper (I/II) species. They proposed that the copper centers function as a Lewis acid to enhance the electrophilicity of the azido group, whereas the other one is a two-electron reducing agent in oxidative metallacycle formation. ${ }^{24}$

At this stage of discussion, we must remember that, as early as 2002, Sharpless et al. noted that even $\mathrm{Cu}(0)$ could be used as a source of the catalytic process, although these reactions took longer to proceed to completion. ${ }^{1,25} \mathrm{Recently} \mathrm{Cu}(0)$ nanoparticules as nanocatalysts were proved to be particularly active in the process. ${ }^{25}$ Copper (II) has been reported to be the reactive catalytic species in other cases as well. ${ }^{26}$

Our copper source was loaded onto a heterogeneous catalyst which hampers direct observation of the oxidation state; therefore indirect measurment might give information about the mechanism. No spectroscopic evidences concerning the formation of the homocoupling 1,3-diyne were found, either by NMR or GC-MS. Thus, reduction to $\mathrm{Cu}(\mathrm{I})$ seems unlikely. 
In order to probe the oxidation state of the copper ions, we studied the influence of an atmosphere of molecular oxygen. Air oxidation of $\mathrm{Cu}(\mathrm{I})$ to $\mathrm{Cu}(\mathrm{II})$ is generally fast (thus explaining the instability of $\mathrm{Cu}(\mathrm{I})$ ions) and has been proven here when copper(I) iodide was introduced into vials that were successively flushed (for 5 min) and kept (for $1 / 2 \mathrm{~h}$ ) separately under either $\mathrm{O}_{2}$ or $\mathrm{Ar}$ atmosphere. Complexation by addition of $\mathrm{NH}_{4} \mathrm{OH}$ solution occurs readily in the case of oxygen producing a blue solution (characteristic for $\mathrm{Cu}^{I I}\left(\mathrm{NH}_{3}\right)_{\mathrm{n}}$ ions). In the case of argon, this blue solution was observed only after few minutes. We have then performed the cycloaddition under $\mathrm{O}_{2}$ atmosphere and shaded from the light (Figure 3). In that case, if $\mathrm{Cu}(\mathrm{I})$ happened to be formed then it would instantly be oxidized to $\mathrm{Cu}(\mathrm{II})$ again. This reaction was monitored by GC-MS and the conversion is complete within 24 hours, just as the classical conditions.

Figure 3. Cycloaddition under $\mathrm{O}_{2}$ atmosphere.

\subsection{Kinetic study}

Further information about the catalysis can be disclosed by comparison between the rates of cycloaddition between $\mathrm{Cu}(\mathrm{I})$ and $\mathrm{Cu}(\mathrm{II})$. In order to have similar reaction conditions (especially heterogeneous) the choice of the $\mathrm{Cu}(\mathrm{I})$ catalyst turned to be copper(I) iodide. Parallel reactions were carried out in $\mathrm{CDCl}_{3}$ using $\mathrm{Cu}(\mathrm{II}) \mathrm{SBA}-15$ (6 mol\%) and $\mathrm{CuI}(0.3$ mol\%) and monitored by ${ }^{1} \mathrm{H}-\mathrm{NMR}$ at given times (Figure 4). At this loading of catalyst, the rate of the reaction involving $\mathrm{Cu}(\mathrm{II}) \mathrm{SBA}-15$ is much higher than the one of $\mathrm{CuI}$ (around 4 times). So if the copper (I) ions are the only one involved in the catalysis, $20 \%$ of the total amount of the $\mathrm{Cu}(\mathrm{II})$ bound to the surface of SBA-15 has to be reduced to $\mathrm{Cu}(\mathrm{I})$, which is highly unlikely to occur. Therefore, copper (II) is believed to play a crucial role for this reaction.

Figure 4. Kinetic experiment. 


\subsection{Acetylide copper intermediate}

Deuterium exchange experiments can also give us insights into the reaction mechanism. We have first prepared ethyl deuteropropiolate under basic classical conditions. GC-MS showed deuterium incorporation over 99\% (Figure 5). This deuterated alkyne was then submitted to the usual cycloaddition conditions. No deuterium was incorporated into the triazole ring (confirmed either by ${ }^{1} \mathrm{H}-\mathrm{NMR}$ and GC-MS) thus indicating the cleavage of the C-D bond and the formation of a copper-carbon bond can be postulated. Therefore, Lewis acidic mechanism (as exemplified with zeolites ${ }^{9 c}$ ) can be ruled out.

Figure 5. Deuteration experiment.

\subsection{A dinuclear mechanism}

Although copper (II) reduction to $\mathrm{Cu}(\mathrm{I})$ by a hydrogen-abstraction/proton-delivery/electrongain mechanism is a remote possibility, ${ }^{26}$ the previous set of experiments led us to hypothesize the formation of the triazole through the following mechanism involving only $\mathrm{Cu}$ (II) species (Figure 6). The complete 1,4-regioselectivity is rationalized through a covalent bond between copper and the alkynes.

Figure 6. Simplified mechanism of the $\mathrm{Cu}(\mathrm{II}) \mathrm{SBA}-15$ catalyzed Huisgen reaction.

It was observed that dinuclear alkynyl copper complexes exhibit superior reactivity toward organic azides compared to their monomeric counterparts. ${ }^{27}$ Such complexes were supposed to be involved in the recent description of the copper catalyzed Huisgen reaction, ${ }^{16 a, 23 c, 26}$ and were recently unveiled. ${ }^{28}$ Since the pore surface of the catalyst is covered with copper (II) atoms, approximately $2 \mathrm{Cu}(\mathrm{II})$ atoms per $\mathrm{nm}^{2}$, we can presume that the formation of a dinuclear complex is not out of the question. Since we have not detected alkyne oxidative homocoupling products, we can hypothesize that the formation of a $\mathrm{Cu}(\mathrm{II})$ acetylide complex 
(Figure 6) is a key and rate-determining step. ${ }^{16 a, 26,28}$ Once the dinuclear alkynyl copper complex is formed, it can undergo a classical evolution via a metallacycle. ${ }^{16 a, 23 c, 26,28}$ Protodemetallation can subsequently occur through internal proton delivery from the residual silanol groups of the surface.

Two supplementary experiments were performed using $\mathrm{Cu}(\mathrm{II})-\mathrm{SBA} 15$ with different porosity or $\mathrm{Cu}$ loading (Figure 7).

Figure 7. Loading and sizes of the pores.

These three results revealed the predominant importance of the loading and reinforced the hypothesis of a bimetallic mechanism. In addition, the pore size may have a great effect on the reactivity as the reaction is believed to occur inside the pores (as corroborated by $\mathrm{N}_{2}$ volumetric adsorption of the catalyst without washing). The influence of these parameters is currently under investigation and will be reported in due time.

\section{Conclusion}

We have shown herein that our $\mathrm{Cu}$ (II) SBA-15 material can be used successfully as a reusable catalyst for an azide-alkyne cycloaddition reaction without degradation. The conversion can be as high as $99 \%$ and a total regioselectivity is obtained. To our knowledge, this is the first time that a copper (II) SBA-15 material has been shown to be active as a reusable catalyst for azide-alkyne cycloaddition reactions.

\section{Acknowledgements}

Nicolas Pasternak is gratefully acknowledge for providing some $\mathrm{Cu}(\mathrm{II}) \mathrm{SBA}-15$ samples and for performing $\mathrm{N}_{2}$-adsoprtion analysis. 


\section{References}

1 V. V. Rostovtsev, L. G. Green, V. V. Fokin, K. B. Sharpless, Angew. Chem. 2002, 114, 2708-2711; Angew. Chem. Int. Ed. 2002, 41, 2596-2599.

2 a) C. W. Tornøe, C. Christensen, M. Meldal, J. Org. Chem. 2002, 67, 3057-3064. b) M. Meldal, C. W. Tornøe, Chem. Rev. 2008, 108, 2952-3015.

3 a) C. Girard, E. Önen, M. Aufort, S. Bauvière, E. Samson, J. Herscovici, Org. Lett. 2006, 8, 1689-1692; b) C. D. Smith, I. R. Baxendale, S. Lanners, J. J. Hayward, S. C. Smith, S. V. Ley, Org. Biomol. Chem. 2007, 5, 1559-1561; c) J. Albadi, M. Keshavarz, Synth. Commun. 2013, 43, 2019-2030; d) U. Sirion, Y. J. Bae, B. S. Lee, D. Y. Chi, Synlett, 2008, 2326-2330.

4 a) A. Coelho, P. Diz, O. Caamaño, E. Sotelo, Adv. Synth. Catal. 2010, 352, 1179-1192; b) P. Diz, A. Coelho, A. El Maatougui, J. Azuaje, O. Caamaño, E. Sotelo, J. Org. Chem. 2013, 78, 6540-6549; c) T. R. Chan, V. V. Fokin, QSAR Comb. Sci. 2007, 26, 1274-1279; d) M. Lammens, J. Skey, S. Wallyn, R. O’Reilly, F. Du Prez, Chem. Commun. 2010, 46, 8719-8721; e) S. Wallyn, M. Lammens, R. O’Reilly, F. Du Prez, J. Polym. Sci. Part A: Polym. Chem. 2011, 49, 2878-2885; f) E. Ozkal, S. Özçubukçu, C. Jimeno, M. A. Pericàs, Catal. Sci. Technol. 2012, 2, 195-200; g) L. Bonami, W. Van Camp, D. Van Rijckegem, F. E. Du Prez, Macromol. Rapid Commun. 2009, 30, 34-38; h) G. M. Pawar, B. Bantu, J. Weckesser, S. Blechert, K. Wurst, M. R. Buchmeiser, Dalton Trans. 2009, 9043-9051; i) M. N. Soltani Rad, S. Behrouz, A. Movahedian, .M. M. Doroodmand, Y. Ghasemi, S. Rasoul-Amini, A.-R. Ahmadi Gandomani, R. Rezaie, Helv. Chim. Acta 2013, 96, 688-701.

5 a) T. Miao, L. Wang, Synthesis 2008, 363-368; b) P. Li, L. Wang, Y. Zhang, Tetrahedron 2008, 64, 10825-10830; c) T. Shamim, S. Paul, Catal. Lett. 2010, 136, 260-265; d) A. Megia-Fernandez, M. Ortega-Muñoz, J. Lopez-Jaramillo, F. Hernandez-Mateo, F. 
Santoyo-Gonzalez, Adv. Synth. Catal. 2010, 352, 3306-3320; e) M. N. Soltani Rad, S. Behrouz, M. M. Doroodmand, A. Movahedian, Tetrahedron 2012, 68, 7812-7821.

6 A. Z. Ahmadi, F. Heidarizadeh, M. Keshavarz, Synth. Commun. 2013, 43, 2100-2109.

7 I. Jlalia, H. Elamari, F. Menagem, J. Herscovici, C. Girard, Tetrahedron Lett. 2008, 49, 6756-6758.

8 a) S. Chassaing, M. Kumarraja, A. Sani Souna Sido, P. Pale, J. Sommer, Org. Lett. 2007, 9, 883-886; b) A. Alix, S. Chassaing, P. Pale, J. Sommer, Tetrahedron 2008, 64, 89228929; c) S. Chassaing, A. Sani Souna Sido, M. Kumarraja, P. Pale, J. Sommer, Chem. Eur. J. 2008, 14, 6713-6721; d) V. Bénéteau, A. Olmos, T. Boningari, J. Sommer, P. Pale, Tetrahedron Lett. 2010, 51, 3673-3677.

9 a) M. Chtchigrovsky, A. Primo, P. Gonzalez, K. Molvinger, M. Robitzer, F. Quignard, F. Taran, Angew. Chem. 2009, 121, 6030-6034; Angew. Chem. Int. Ed. 2009, 48, 59165920; b) K. Martina, S. E. S. Leonhardt, B. Ondruschka, M. Curini, A. Binello, G. Cravotto, J. Mol. Catal. A: Chem. 2011, 334, 60-64.

11 a) T. Katayama, K. Kamata, K. Yamaguchi, N. Mizuno, ChemSusChem 2009, 2, 59-62; b) N. Mukherjee, S. Ahammed, S. Bhadra, B. C. Ranu, Green Chem. 2013, 15, 389-397.

12 a) M. Ciyabi Hashjin, R. Ciyabi, M. Baharloui, G. Hosseini, H. Tavakoli, Chin. J. Chem. 2012, 30, 223-227; b) H. Sarghi, A. Koshnood, M. M. Doroodmand, R. Khalifeh, J. Iran. Chem. Soc. 2012, 9, 231-250.

13 K. Yamaguchi, T. Oishi, T. Katayama, N. Mizuno, Chem. Eur. J. 2009, 15, 10464-10472. 14 a) Y. Wang, J. Liu, C. Xia, Adv. Synth. Catal. 2011, 353, 1534-1542; b) Y. M. A. Yamada, S. M. Sarkar, Y. Uozumi, J. Am. Chem. Soc. 2012, 134, 9285-9290; c) S. Roy, T. Chatterjee, S. Manirul Islam, Green Chem. 2013, 15, 2532-2539. 
15 a) K. Kamata, Y. Nakagawa, K. Yamaguchi, N. Mizuno, J. Am. Chem. Soc. 2008, 130, 15304-15310; b) K. V. Purnima, D. Sreenu, N. Bhasker, K. Nagaiah, N. Lingaiah, B. V. Subba Reddy, J. S. Yadav, Chin. J. Chem. 2013, 31, 534-538.

16 a) K. Namitharan, M. Kumarraja, K. Pitchumani, Chem. Eur. J. 2009, 15, 2755-2758; b) A. N. Prasad, B. Thirupathi, G. Raju, R. Srinivas, B. M. Reddy, Catal. Sci. Technol. 2012, 2, 1264-1268; c) Y. Masuyama, K. Yoshikawa, N. Suzuki, K. Hara, A. Fukuoka, Tetrahedron Lett. 2011, 52, 6916-6918; d) S. Mohammed, A. K. Padala, B. A. Dar, B. Singh, B. Sreedhar, R. A. Vishwakarma, Tetrahedron 2012, 68, 8156-8162.

17 a) K. Rajender Reddy, K. Rajgopal, M. Lakshmi Kantam, Catal. Lett. 2007, 114, 36-40; b) B. Kaboudin, Y. Abedi, T. Yokomatsu, Org. Biomol. Chem. 2012, 10, 4543-4548; c) R. B. N. Baig, R. S. Varma, Green Chem. 2013, 15, 1839-1843.

18 R. Aït Youcef, M. Dos Santos, S. Roussel, J.-P. Baltaze, N. Lubin-Germain, J. Uziel, J. Org. Chem. 2009, 74, 4318-4323.

19 a) Y. Wang, Z. Wu, J. Zhu, J. Solid State Chem. 2004, 177, 3815-3823; b) L. Jiao, J. Regalbuto, J. Catal. 2008, 260, 342-350; c) L. Chmielarz, P. Kustrowski, R. Dziembaj, P. Cool, E. Vansant, Appl. Catal. B 2006, 62, 369-380.

20 N. Brodie-Linder, G. Dosseh, C. Alba-Simionesco, F. Audonnet, M. Impéror-Clerc, Mater. Chem. Phys. 2008, 108, 73-81.

21 N. Brodie-Linder, R. Besse, F. Audonnet, S. LeCaer, J. Deschamps, M. Impéror-Clerc, C. Alba-Simionesco, Micropor. Mesopor. Mater. 2010, 132, 518-525.

22 N. Brodie-Linder, R. Besse, F. Audonnet, S. LeCaer, J. Deschamps, M. Impéror-Clerc, C. Alba-Simionesco, Micropor. Mesopor. Mater. 2010, 132, 518-525.

23 D. Urankar, M. Steinbücher, J. Kosjek, J. Košmrlj, Tetrahedron 2010, 66, 2602-2613.

24 K. R. Reddy, K. Rajgopal, M. L. Kantam, Synlett 2006, 957-959. 
25 a) W. S. Brotherton, H. A. Michaels, J. T. Simmons, R. J. Clark, N. S. Dalal, L. Zhu, Org. Lett. 2009, 11, 4954-4957; b) G.-C. Kuang, H. A. Michaels, J. T. Simmons, R. J. Clark, L. Zhu, J. Org. Chem. 2010, 75, 6540-6548; c) G.-C. Kuang, P. M. Guha, W. S. Brotherton, J. T. Simmons, L. A. Stankee, B. T. Nguyen, R. J. Clark, L. Zhu, J. Am. Chem. Soc. 2011, 133, 13984-14001.

26 F. Himo, T. Lovell, R. Hilgraf, V. V. Rostovtsev, L. Noodleman, K. B. Sharpless, V. V. Fokin, J. Am. Chem. Soc. 2005, 127, 210-216.

27 B. J. Borah, D. Dutta, P. P. Saikia, N. C. Barua, D. K. Dutta, Green Chem. 2011, 13, $3453-3460$.

28 D. Barreca, E. Fois, G. Gasparotto, R. Saraglia, E. Tondello, G. Tabacchi, Chem. Eur. J. 2011, 17, 10864-10870.

29 M. Ahlquist, V. V. Fokin, Organometallics 2007, 26, 4389-4391.

30 B. T. Worrell, J. A. Malik, V. V. Fokin, Science 2013, 340, 457-460. 


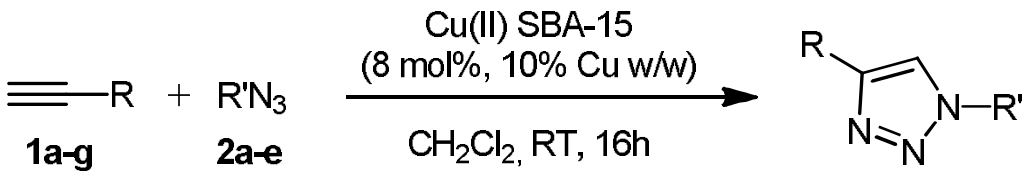

$$
\begin{aligned}
& \text { 3aa-gb } \\
& \text { sole regioisomer }
\end{aligned}
$$

\begin{tabular}{|c|c|c|c|}
\hline Entry & Alkyne 1: R & Azide 2: R' & $\begin{array}{c}\text { Product 3: } \\
\text { Yield* }^{*}\end{array}$ \\
\hline 1 & 1a: COOEt & 2a: $\mathrm{PhCH}_{2}$ & 3aa: $98 \%$ \\
\hline 2 & 1a: COOEt & 2b: $\mathrm{EtOCOCH}_{2}$ & 3ab: $76 \%$ \\
\hline 3 & 1a: COOEt & 2c: $p-\mathrm{F}-\mathrm{C}_{6} \mathrm{H}_{4} \mathrm{CH}_{2}$ & 3ac: $99 \%$ \\
\hline 4 & 1a: COOEt & 2d: 2-oxolan- $\mathrm{CH}_{2}$ & 3ad: $87 \%$ \\
\hline 5 & 1a: COOEt & 2e: $\mathrm{HOCH}_{2} \mathrm{CH}_{2}$ & 3ae: $64 \%$ \\
\hline 6 & 1b: $(\mathrm{EtO})_{2} \mathrm{CH}$ & 2a: $\mathrm{PhCH}_{2}$ & 3ba: $83 \%$ \\
\hline 7 & 1b: $(\mathrm{EtO})_{2} \mathrm{CH}$ & 2b: $\mathrm{EtOCOCH}_{2}$ & 3bb: $66 \%$ \\
\hline 8 & 1b: $(\mathrm{EtO})_{2} \mathrm{CH}$ & 2d: 2-oxolan- $\mathrm{CH}_{2}$ & 3bd: $56 \%(\dagger)$ \\
\hline 9 & 1b: $(\mathrm{EtO})_{2} \mathrm{CH}$ & 2e: $\mathrm{HOCH}_{2} \mathrm{CH}_{2}$ & 3be: $35 \%$ \\
\hline 10 & 1c: $\mathrm{BrCH}_{2} \mathrm{CH}_{2}$ & 2a: $\mathrm{PhCH}_{2}$ & 3ca: $67 \%$ \\
\hline 11 & 1c: $\mathrm{BrCH}_{2} \mathrm{CH}_{2}$ & 2b: $\mathrm{EtOCOCH}_{2}$ & 3cb: $72 \%$ \\
\hline 12 & 1c: $\mathrm{BrCH}_{2} \mathrm{CH}_{2}$ & 2c: $p-\mathrm{F}-\mathrm{C}_{6} \mathrm{H}_{4} \mathrm{CH}_{2}$ & 3cc: $98 \%$ \\
\hline 13 & 1c: $\mathrm{BrCH}_{2} \mathrm{CH}_{2}$ & 2d: 2-oxolan- $\mathrm{CH}_{2}$ & 3cd: $57 \%$ \\
\hline 14 & 1c: $\mathrm{BrCH}_{2} \mathrm{CH}_{2}$ & 2e: $\mathrm{HOCH}_{2} \mathrm{CH}_{2}$ & 3ce: $52 \%$ \\
\hline
\end{tabular}


15

16

17

18

19

20

21

22 1d: $\mathrm{CH}_{2} \mathrm{OH}$

1d: $\mathrm{CH}_{2} \mathrm{OH}$

1d: $\mathrm{CH}_{2} \mathrm{OH}$

1d: $\mathrm{CH}_{2} \mathrm{OH}$

1d: $\mathrm{CH}_{2} \mathrm{OH}$

1e: $\mathrm{CH}_{2} \mathrm{NH}_{2}$

1f: $n-\mathrm{C}_{6} \mathrm{H}_{13}$

1g: 2,3,4,6-tetra- $O$-benzyl- $\beta$-D-

glucopyranosyl 2a: $\mathrm{PhCH}_{2}$

3da: $68 \%$

2b: $\mathrm{EtOCOCH}_{2}$

3db: $65 \%$

2c: $p-\mathrm{F}-\mathrm{C}_{6} \mathrm{H}_{4} \mathrm{CH}_{2} \quad$ 3dc: $72 \%$

2d: 2-oxolan- $\mathrm{CH}_{2}$

3dd: $46 \%$

2e: $\mathrm{HOCH}_{2} \mathrm{CH}_{2}$

3de: $26 \%$

2a: $\mathrm{PhCH}_{2}$

3ea: $17 \%$

2b: $\mathrm{EtOCOCH}_{2}$

3fb: - 




$$
\begin{aligned}
& \text { sole regioisomer }
\end{aligned}
$$

\begin{tabular}{|c|c|c|}
\hline Entry & $\mathrm{Cu}(\mathrm{II}) \mathrm{SBA}-15$ & Conversion $^{*}$ \\
\hline 1 & - & Traces \\
\hline 2 & $4 \mathrm{~mol} \%$ & $34 \%$ \\
\hline 3 & $8 \mathrm{~mol} \%$ & $75 \%$ \\
\hline 4 & $16 \mathrm{~mol} \%$ & $100 \%$ \\
\hline
\end{tabular}



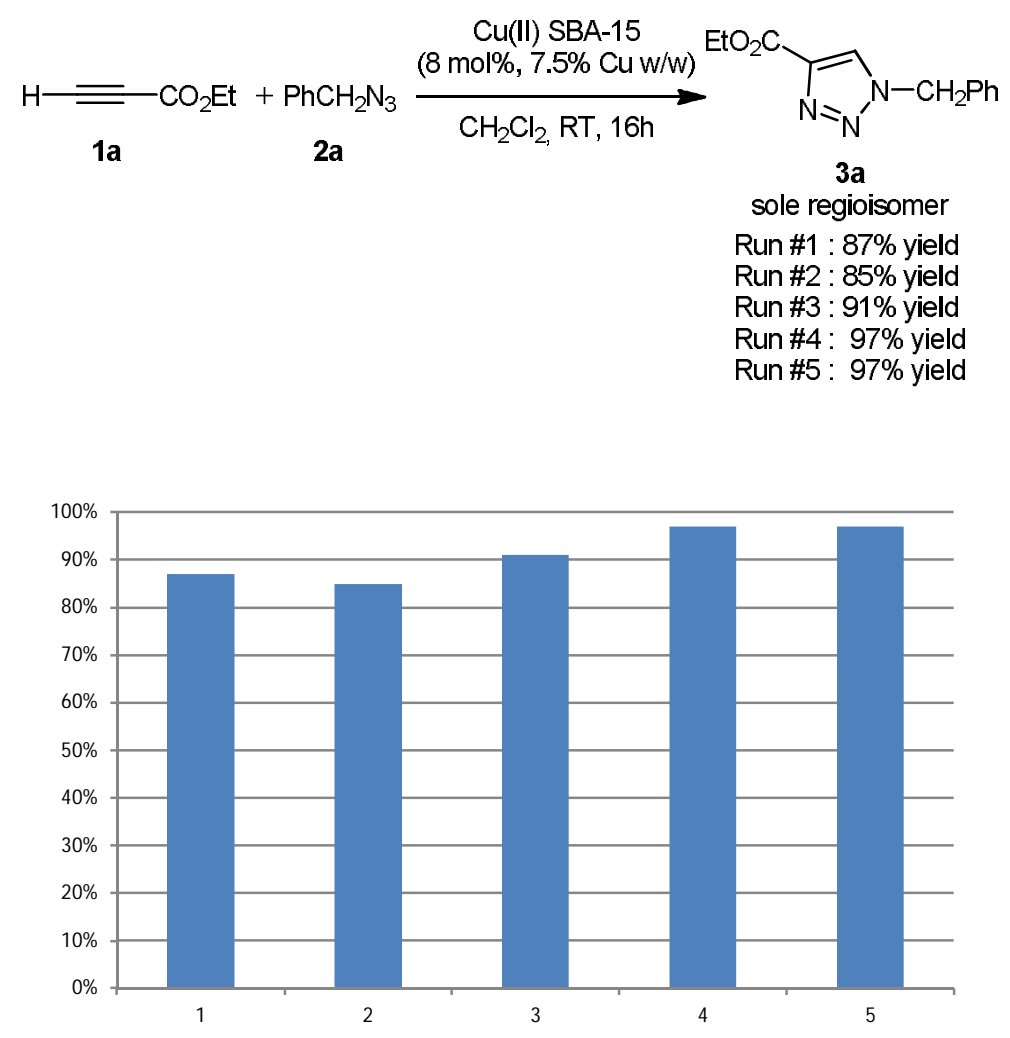


\section{Figure}

$$
\begin{aligned}
& \mathrm{Cu}(\mathrm{II}) \mathrm{SBA}-15 \\
& \mathrm{H}=\mathrm{CO}_{2} \mathrm{Et}+\mathrm{PhCH}_{2} \mathrm{~N}_{3} \stackrel{(6 \mathrm{~mol} \%, 7.5 \% \mathrm{Cu} \mathrm{w} / \mathrm{w})}{\longrightarrow} \\
& \text { 1a } \\
& \text { 2a } \\
& \begin{array}{l}
\mathrm{O}_{2}(1 \text { atm), dark } \\
\mathrm{CH}_{2} \mathrm{Cl}_{2}, \mathrm{RT}, 24 \mathrm{~h}
\end{array}
\end{aligned}
$$

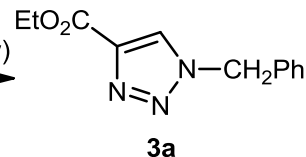

$$
\begin{aligned}
& \text { sole regioisomer }
\end{aligned}
$$




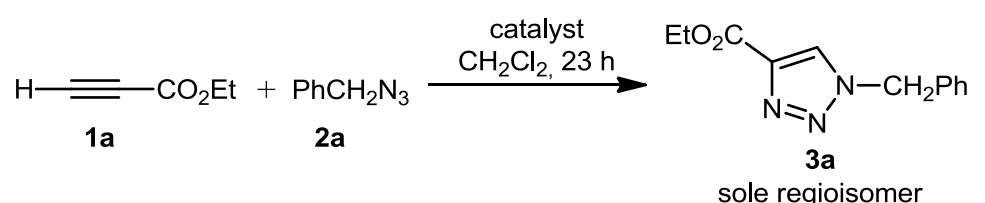

cat $=\mathrm{Cu}(\mathrm{II}) \mathrm{SBA}-15(6 \mathrm{~mol} \%) \quad 100 \%$ conversion $(94 \%$ isolated yield $)$

Cul $(0.3 \mathrm{~mol} \%)$ $\sim 50 \%$ conversion

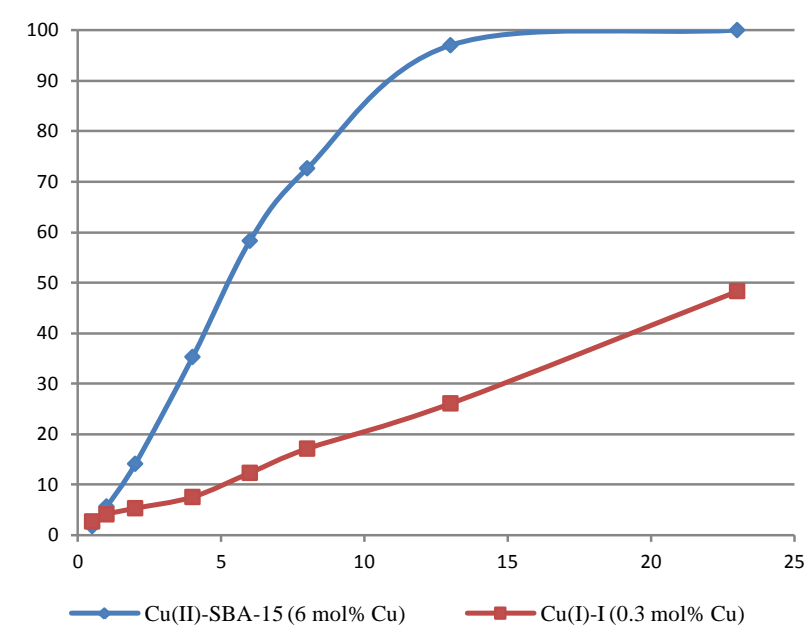




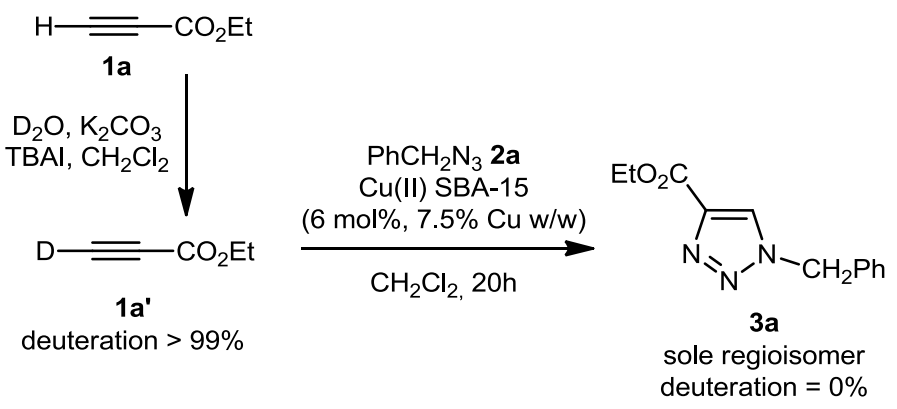




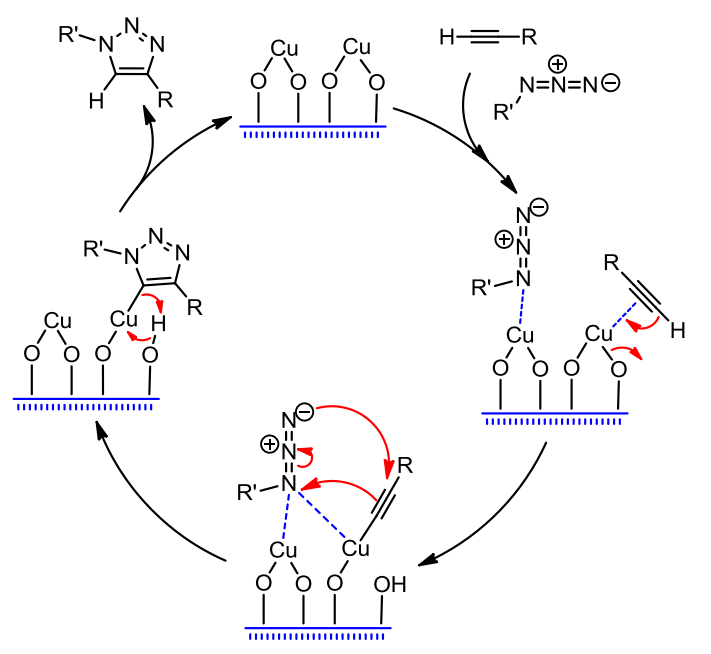




\section{Copper(II) SBA-15: a reusable catalyst for azide-alkyne cycloaddition}

Ibtissem Jlalia ${ }_{b}^{a}$ Florian Gallier, ${ }^{\mathrm{b}}$ Nancy Brodie-Linder, ${ }^{\mathrm{b}, \mathrm{c}, *}$ Jacques Uziel, ${ }^{\mathrm{b}}$ Jacques Augé, ${ }^{b}$ and Nadège Lubin-Germain,

a Laboratoire des Substances Naturelles, INRAP-Pôle Technologique, Sidi Thabet 2020, Tunisia

b Laboratoire de Synthèse Organique Sélective et Chimie bioOrganique, EA 4505, University of CergyPontoise, F-95000 Cergy-Pontoise cedex, France

Phone: (+33) 1-34-25-70-54; fax: (+33) 1-34-25-73-78; e-mail: nadege.lubin-germain@u-cergy.fr

c Laboratoire Léon Brillouin, CEA Saclay, Bât. 563, F-91191 Gif-sur-Yvette, France

\section{Outline}

General Informations. 2

Characterization of the mesoporous $\mathrm{Cu}(\mathrm{II}) \mathrm{SBA}-15$ .2

General Procedure for Cu(II) SBA-15 Azide-Alkyne Cycloaddition 4

General procedure for catalyst recycling .9 


\section{General Informations}

${ }^{1} \mathrm{H}$ and ${ }^{13} \mathrm{C}$ NMR spectra were recorded in a suitable deuterated solvent on a Bruker DPX-250 (250 MHz for ${ }^{1} \mathrm{H} \& 42.5 \mathrm{MHz}$ for ${ }^{13} \mathrm{C}$ ) or on a Jeol 400-ECX (400 MHz for ${ }^{1} \mathrm{H} \& 100 \mathrm{MHz}$ for ${ }^{13} \mathrm{C}$ ). High resolution mass spectra were obtained with an MS Jeol 700 spectrometer or a LTQ orbitrap spectrometer. Optical rotations were determined at $25^{\circ} \mathrm{C}$ in $\mathrm{CHCl}_{3}, 589 \mathrm{~nm}$, on a JASPO DIP 370 instrument and IR spectra were recorded on a Bruker Tensor 27 spectrophotometer. Melting points (uncorrected) were determined on a Buchi B-545. Elemental analyses were done at the Central Service of Analysis (CNRS, Vernaison). Thin layer chromatography was carried out on silica gel plates (Macherey-Nagel), spots were detected with UV light and revealed with $\mathrm{H}_{2} \mathrm{SO}_{4}$ solution. Flash chromatography was performed with silica gel 60, 40-63 $\mu \mathrm{m}$.

Copper content was determined on a JASCO UV Spectrometer.

Nitrogen adsorption of the prepared SBA-15 materials was measured with a BELJAPAN volumetric adsorption analyser model BELSORP-MINI II (BelJapan, Inc., Japan). Before measurements, the SBA-15 Cu materials were pre-treated under vacuum at $383 \mathrm{~K}$ for $24 \mathrm{~h}$. BET (Brunauer-Emmett-Teller) surface area was calculated from the N2 adsorption data in a relative pressure range from 0.05 to 0.2 . We checked that the regression coefficient was greater than 0.999 . The cross sectional area of the nitrogen molecule was assumed to be 16.2 $\AA 2$. The pore volume was estimated from the amount of nitrogen adsorbed at a relative pressure corresponding at the end of the capillary condensation (typically 0.80). The mesoporous size distribution was determined from the adsorption branch of the isotherms using the BJH method. ${ }^{1}$

\section{Characterization of the mesoporous $\mathrm{Cu}(\mathrm{II}) \mathrm{SBA}-15$}

The SBA-15 material was prepared according to a well-established procedure. ${ }^{2}$ This mesoporous silica $(50 \mathrm{mg}$ ) was then suspended for $10 \mathrm{~min}$ at room temperature in $20 \mathrm{~mL}$ of a $5 \cdot 10^{-2} \mathrm{~mol} / \mathrm{L}$ aqueous solution of $\mathrm{Cu}\left(\mathrm{NO}_{3}\right)_{2} \cdot 3 \mathrm{H}_{2} \mathrm{O}$ containing a particular amount of a solution of $28 \%(\mathrm{w} / \mathrm{w}) \mathrm{NH}_{4} \mathrm{OH}$ in order to obtain $\mathrm{pH} 10.5 .^{3}$ The material was then filtered, washed profusely with water to ensure the removal of all free $\mathrm{Cu}$ (II) ions and dried in an oven at $60^{\circ} \mathrm{C}$ for $4 \mathrm{~h}$ to give a bluish solid. Control of the time and $\mathrm{pH}$ of impregnation is crucial for the copper loading.

The copper uptake was then determined by UV-visible spectroscopy. A sample of $\mathrm{Cu}$ (II) SBA-15 (10 mg) is suspended in $5 \mathrm{~mL} 2 \%(\mathrm{w} / \mathrm{w})$ aqueous $\mathrm{HNO}_{3}$ and stirred for 15 minutes at room temperature, vigorously in order to ensure the best homogeneity possible in

\footnotetext{
${ }^{1}$ E.P.Barrett, L.G.Joyner, P.P. Halenda, J. Am. Chem. Soc. 1951, 73, 373-380

${ }^{2}$ N. Brodie-Linder, G. Dosseh, C. Alba-Simionesco, F. Audonnet, M. Impéror-Clerc, Mater. Chem. Phys. 2008, 108, 73-81.

${ }^{3}$ N. Brodie-Linder, R. Besse, F. Audonnet, S. LeCaer, J. Deschamps, M. Impéror-Clerc, C. Alba-Simionesco, Micropor. Mesopor. Mater. 2010, 132, 518-525.
} 
solution and filtered. UV absorbance of the solution was measured and the copper content was calculated with the standard calibration curve.

Each batch of $\mathrm{Cu}$ (II) SBA-15 is further characterized by IR spectroscopy and $\mathrm{N}_{2-}$ adsorption measurement. The following table gives the detailed values of Pore volume and Pore diameter as well as the BET Surface area for the freshly prepared Cu(II) SBA-15, the $\mathrm{Cu}(\mathrm{II}) \mathrm{SBA}-15$ after several runs (simply filtered after the last run) and the $\mathrm{Cu}(\mathrm{II}) \mathrm{SBA}-15$ thoroughly rinsed after the last run.

\begin{tabular}{|c|c|c|c|}
\hline & $\mathrm{V}_{\mathrm{p}}$, Pore volume $\left(\mathrm{cm}^{3} \mathrm{~g}^{-1}\right)$ & $\mathrm{A}_{\mathrm{BET}}$, Surface area $\left(\mathrm{m}^{2} \mathrm{~g}^{-1}\right)$ & $\mathrm{d}_{\mathrm{p}}$, Pore diameter $(\mathrm{nm})$ \\
\hline Native Cu(II) SBA-15 & 0.483 & 306 & 7.0 \\
\hline $\mathrm{Cu}(\mathrm{II})$ SBA-15 after runs & 0.281 & 191 & 5.5 \\
\hline $\begin{array}{c}\mathrm{Cu}(\mathrm{II}) \text { SBA-15 after } \\
\text { rinsing with acetonitrile }\end{array}$ & 0.408 & 261 & 6.2 \\
\hline
\end{tabular}

We can clearly see a decrease in pore volume and diameter and surface area in the material after several runs of reaction and without rinsing. The deformation of the hysteresis loop indicates a variation in pore size or some pore blocking. This can be attributed to the organic materials remaining from the reaction. After intensive rinsing, the different values increase and approach those of the original material before the catalytic runs. The slight differences can be explained by complexation of $\mathrm{CH}_{3} \mathrm{CN}$ to the copper thus reducing the different parameters.

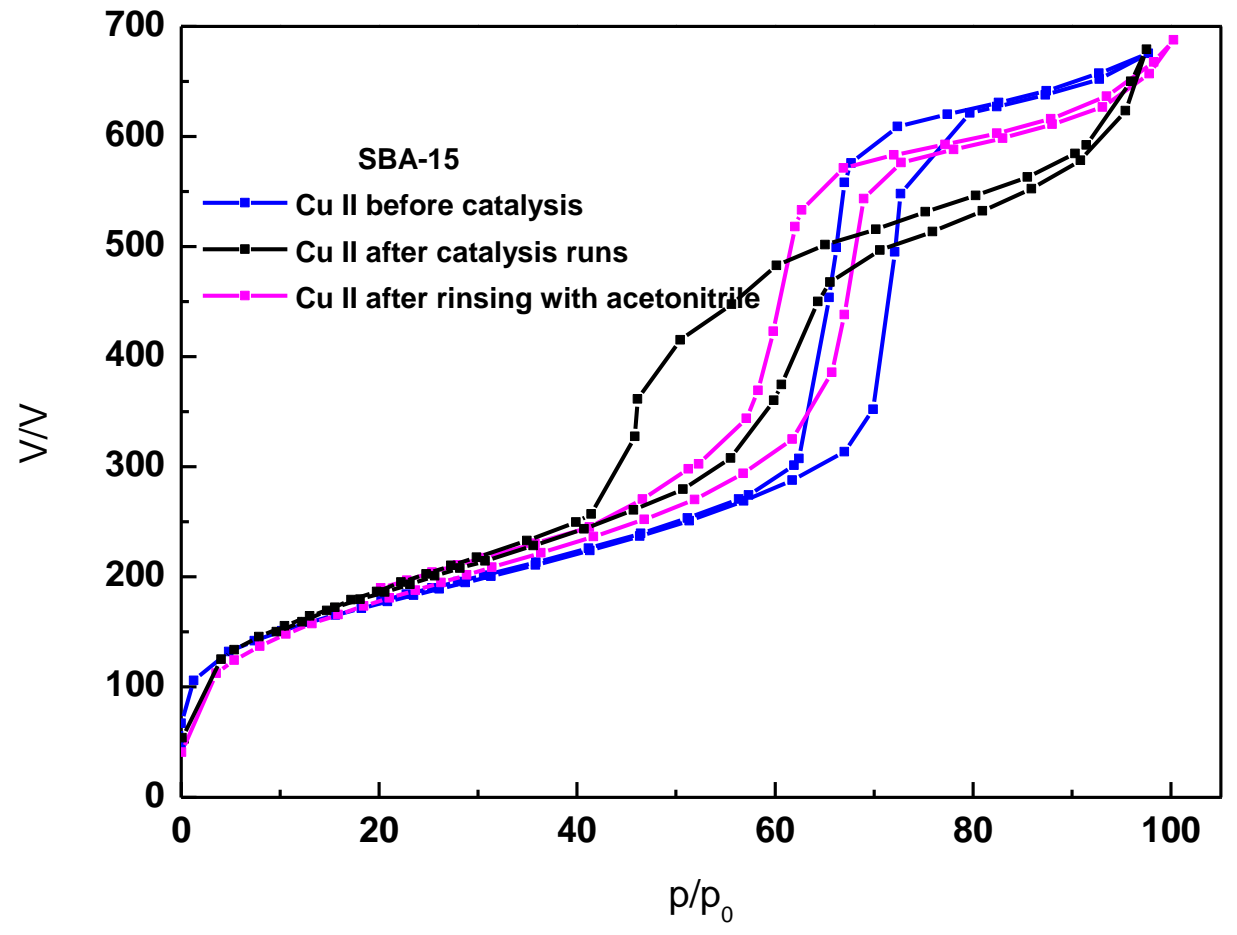

Figure 1: $\mathrm{N}_{2}$-adsorption of $\mathrm{Cu}(\mathrm{II}) \mathrm{SBA}-15$ 


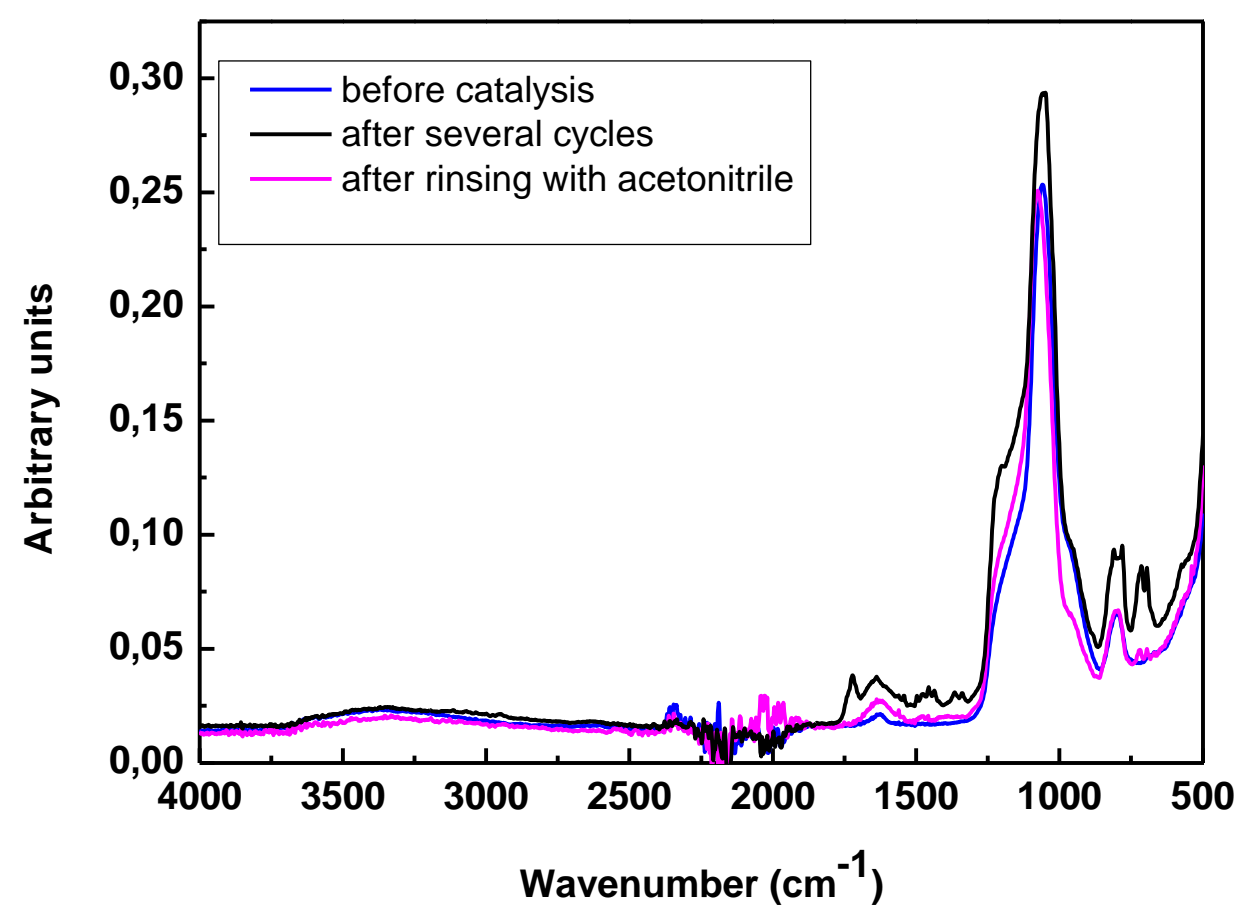

Figure 2: IR analysis of $\mathrm{Cu}(\mathrm{II}) \mathrm{SBA}-15$

\section{General Procedure for Cu(II) SBA-15 Azide- Alkyne Cycloaddition}

Alkyne (0.5 mmol), azide $(0.55 \mathrm{mmol})$ and $\mathrm{Cu}(\mathrm{II}) \mathrm{SBA}-15(25 \mathrm{mg}, 8 \mathrm{~mol} \% \mathrm{Cu})$ were stirred in dichloromethane $(2 \mathrm{~mL})$ overnight. The mixture was filtered and the solid was washed twice with $2 \mathrm{~mL}$ of dichloromethane. The filtrate was concentrated by evaporation under vacuum. Excess of azide can be removed after immobilization on a triphenylphosphine resin. In the case of highly polar substrates, the solid was washed twice with $2 \mathrm{~mL}$ of acetonitrile.

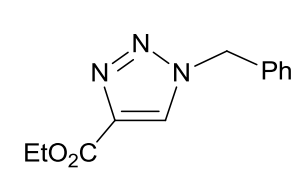

Ethyl 1-benzyl-1,2,3-triazole-4-carboxylate (3aa) ${ }^{\mathbf{4}}$ : Prepared from $49 \mathrm{mg}$ $(0.50 \mathrm{mmol})$ of propiolic acid ethyl ester and $73 \mathrm{mg}(0.55 \mathrm{mmol})$ of benzyl azide. The product was obtained as an off-white solid (113 mg, $98 \%)$. mp: 93-94 ${ }^{\circ} \mathrm{C}$. FTIR: $v$ 3112, 3066, 3038, 2849, 1725, 1538, 1239 and $1048 \mathrm{~cm}^{-1} .{ }^{1} \mathrm{H}$ NMR (250 $\left.\mathrm{MHz}, \mathrm{CDCl}_{3}\right): \delta 1.21(\mathrm{t}, J=7.2 \mathrm{~Hz}, 3 \mathrm{H}), 4.21-4.16(\mathrm{~m}, 2 \mathrm{H}), 5.14(\mathrm{~s}, 2 \mathrm{H}), 7.31-7.28(\mathrm{~m}, 1 \mathrm{H})$,

\footnotetext{
${ }^{4}$ S. Chassaing, M. Kumarraja, A. Sani Souna Sido, P. Pale, J. Sommer, Org. Lett. 2007, 9, 883-886
} 
7.37-7.34 (m, 2H), 7.82-7.79 (m, 2H) and $7.95(\mathrm{~s}, 1 \mathrm{H}) .{ }^{13} \mathrm{C} \mathrm{NMR}\left(75.5 \mathrm{MHz}, \mathrm{CDCl}_{3}\right): \delta 13.7$, 50.5, 62.0, 121.1, 125.4, 127.9, 128.5, 130.1, 147.6, 166.1 ppm. LC-MS: ELSD pur. $98 \%$, UV pur. $100 \% ; \mathrm{R}_{\mathrm{t}}=4.75 \mathrm{~min} ; \mathrm{m} / z: 232\left([\mathrm{M}+\mathrm{H}]^{+}\right)$.



Ethyl 1-(ethoxycarbonylmethyl)-1,2,3-triazole-4-carboxylate (3ab): ${ }^{5}$ Prepared from $50 \mu \mathrm{L}(0.50 \mathrm{mmol})$ of propiolic acid methyl ester and $71 \mathrm{mg}(0.55 \mathrm{mmol})$ of ethyl azidoacetate. The product was obtained as a beige solid (86 mg, $76 \%$ ). mp: 100-102 ${ }^{\circ} \mathrm{C}$. FTIR: $v 3111,2986,1757,1718$, 1534, 1463, 1375, 1253 and $1022 \mathrm{~cm}^{-1} .{ }^{1} \mathrm{H}$ NMR $\left(250 \mathrm{MHz}, \mathrm{CDCl}_{3}\right): \delta 1.26(\mathrm{t}, J=7.5 \mathrm{~Hz}$, $3 \mathrm{H}), 1.36(\mathrm{t}, J=7.5 \mathrm{~Hz}, 3 \mathrm{H}), 4.22(\mathrm{q}, J=7.5 \mathrm{~Hz}, 2 \mathrm{H}), 4.40(\mathrm{q}, J=7.5 \mathrm{~Hz}, 2 \mathrm{H}), 5.22(\mathrm{~s}, 2 \mathrm{H})$, 8.26 (s, 1H). ${ }^{13} \mathrm{C}$ NMR $\left(75.5 \mathrm{MHz}, \mathrm{CDCl}_{3}\right): \delta 14.0,14.3,51.0,61.4,62.7,160.5,165.7 \mathrm{ppm}$. LC-MS: ELSD pur. $91 \%$, UV pur. $100 \% ; \mathrm{R}_{\mathrm{t}}=5.37 \mathrm{~min} ; \mathrm{m} / z: 228\left([\mathrm{M}+\mathrm{H}]^{+}\right)$.



Ethyl 1-(4-fluorobenzyl)-1,2,3-triazole-4-carboxylate (3ac):

Prepared from $50 \mu \mathrm{L}(0.50 \mathrm{mmol})$ of propiolic acid methyl ester and $83 \mathrm{mg}(0.55 \mathrm{mmol})$ of 4-fluorobenzylazide. The product was obtained as a beige solid (123 mg, 99\%). mp: $102-104^{\circ} \mathrm{C}$. FTIR: $v 3134,2981,1715,1538$, 1220, $1045 \mathrm{~cm}^{-1} .{ }^{1} \mathrm{H}$ NMR $\left(250 \mathrm{MHz}, \mathrm{CDCl}_{3}\right): \delta 1.30(\mathrm{t}, J=7.5 \mathrm{~Hz}, 3 \mathrm{H}), 4.32(\mathrm{q}, J=7.5 \mathrm{~Hz}$, $2 \mathrm{H}), 5.49(\mathrm{~s}, 2 \mathrm{H}), 7.22-6.82(\mathrm{~m}, 4 \mathrm{H}), 7.96(\mathrm{~s}, 1 \mathrm{H}) \mathrm{ppm} .{ }^{13} \mathrm{C} \mathrm{NMR}(62.5 \mathrm{MHz}, \mathrm{CDCl} 3): \delta$ $14.3,53.7,61.3,116.3\left(\mathrm{~d}, J_{\mathrm{C}-\mathrm{F}}=21.8 \mathrm{~Hz}\right), 129.7\left(\mathrm{~d}, J_{\mathrm{C}-\mathrm{F}}=3.5 \mathrm{~Hz}\right), 130.2\left(\mathrm{~d}, J_{\mathrm{C}-\mathrm{F}}=8.5 \mathrm{~Hz}\right)$, 130.4, $160.8\left(\mathrm{~d}, J_{\mathrm{C}-\mathrm{F}}=25.9 \mathrm{~Hz}\right), 165.0 \mathrm{ppm}$. HRMS: Calcd for $\mathrm{C}_{12} \mathrm{H}_{12} \mathrm{~N}_{3} \mathrm{O}_{2} \mathrm{~F}: 249.0914$. Found: 249.0913.

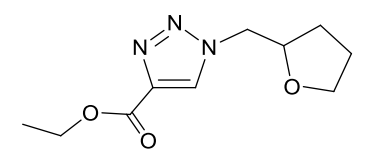

Ethyl 1-((tetrahydrofuran-2-yl)-1,2,3-methyl)triazole-4-carboxylate (3ad): Prepared from $50 \mu \mathrm{L}(0.50 \mathrm{mmol})$ of propiolic acid methyl ester and $69 \mathrm{mg}(0.55 \mathrm{mmol})$ of 2-(azidomethyl)-tetrahydrofurane. The product was obtained as a yellow oil (97 mg, 87\%). FTIR: v 3134, 2978, 1718, 1540, 1463, 1225, 1039. ${ }^{1} \mathrm{H}$ NMR $\left(250 \mathrm{MHz}, \mathrm{CD}_{3} \mathrm{CN}\right): \delta 1.1(\mathrm{~m}, 1 \mathrm{H}), 1.6(\mathrm{~m}, 1 \mathrm{H}), 1.8(\mathrm{~m}, 1 \mathrm{H}), 2.05(\mathrm{~m}$, $1 \mathrm{H}), 3.7(\mathrm{~m}, 1 \mathrm{H}), 3.8(\mathrm{~m}, 1 \mathrm{H}), 4.2(\mathrm{~m}, 1 \mathrm{H}), 4.33(\mathrm{~m}, 3 \mathrm{H}), 4.5(\mathrm{~m}, 1 \mathrm{H}) .{ }^{13} \mathrm{C} \mathrm{NMR}(62.5 \mathrm{MHz}$, $\left.\mathrm{CD}_{3} \mathrm{CN}\right): \delta 14.5,26.2,29.2,54.7,62.7,68.9,77.7,129.9,142.0,161.7$. HRMS: Calcd for $\mathrm{C}_{10} \mathrm{H}_{16} \mathrm{~N}_{3} \mathrm{O}_{3}$ : 226.1192. Found: 226.1188.



Ethyl 1-(2-hydroxyethyl)-1,2,3-triazole-4-carboxylate $\quad$ (3ae) $^{\mathbf{6}}$ : Prepared from $50 \mu \mathrm{L}(0.50 \mathrm{mmol})$ of propiolic acid methyl ester and

\footnotetext{
${ }^{5}$ Palacios, F.; Ochoa de Retana, A. M.; Pagalday, J.; Sanchez, J. M. Org. Prep. Proced. Int. 1995, 27, 603-612

${ }^{6}$ A. Megia-Fernandez, M. Ortega-Muñoz, J. Lopez-Jaramillo, F. Hernandez-Mateo, F. Santoyo-Gonzalez, Adv. Synth. Catal. 2010, 352, 3306-3320
} 
$47 \mathrm{mg}(0.55 \mathrm{mmol})$ of 2-azidoethanol. The product was obtained as a yellow oil $(60 \mathrm{mg}$, 64\%). FTIR: $v$ 3365, 3138, 2938, 1718, 1542, 1203, 1040. ${ }^{1} \mathrm{H}$ NMR $\left(250 \mathrm{MHz}, \mathrm{CD}_{3} \mathrm{CN}\right): \delta$ $1.2(\mathrm{t}, J=7.5,3 \mathrm{H}), 3.1(\mathrm{t}, \mathrm{OH}), 3.9(\mathrm{~m}, 2 \mathrm{H}), 4.35(\mathrm{q}, J=7.5,2 \mathrm{H}), 4.45(\mathrm{~m}, 2 \mathrm{H}), 8.3(\mathrm{~s}, 1 \mathrm{H})$. ${ }^{13} \mathrm{C}$ NMR (69.9 MHz, $\left.\mathrm{CD}_{3} \mathrm{CN}\right): \delta$ 14.5, 53.7, 61.1, 61.7, 129.8 ppm. HRMS: Calcd for $\mathrm{C}_{7} \mathrm{H}_{12} \mathrm{~N}_{3} \mathrm{O}_{3}$ : 186.0879. Found: 186.0874 .

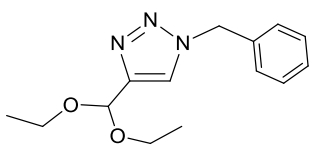

1-Benzyl-4-diethoxymethyl-1,2,3-triazole (3ba) ${ }^{7}$ : Prepared from $72 \mu \mathrm{L}$ $(0.50 \mathrm{mmol})$ of propiolaldehyde diethyl acetal and $73 \mathrm{mg}(0.55 \mathrm{mmol})$ of benzyl azide. The product was obtained as a yellow solid (108 $\mathrm{mg}, 83 \%)$. $\mathrm{mp}=60^{\circ} \mathrm{C}$. FTIR: $v 3120,3073,2983,2929,2891,1455,1267,1094,1052 .{ }^{1} \mathrm{H}$ NMR $(300$ $\left.\mathrm{MHz}, \mathrm{CDCl}_{3}\right): \delta 1.21(\mathrm{t}, J=7.0 \mathrm{~Hz}, 6 \mathrm{H}), 3.62(2 \mathrm{q}, J=7.1 \mathrm{~Hz}, 4 \mathrm{H}), 5.50(\mathrm{~s}, 2 \mathrm{H}), 5.68(\mathrm{~s}, 1 \mathrm{H})$, 7.25-7.35 (m, 5H), $7.49(\mathrm{~s}, 1 \mathrm{H}) .{ }^{13} \mathrm{C}$ NMR $\left(75.5 \mathrm{MHz}, \mathrm{CDCl}_{3}\right): \delta 15.1,54.2,61.6,96.8$, $121.8,128.1,128.7,129.1,134.5,147.5$. LC-MS: ELSD pur. $100 \%$, UV pur. $100 \% ; \mathrm{R}_{\mathrm{t}}=8.35$ $\min ; m / z: 234\left(\left[\mathrm{M}+\mathrm{H}-\left(\mathrm{CH}_{2} \mathrm{CH}_{2}\right)\right]^{+}, 90 \%\right), 284\left([\mathrm{M}+\mathrm{Na}]^{+}, 10 \%\right)$.

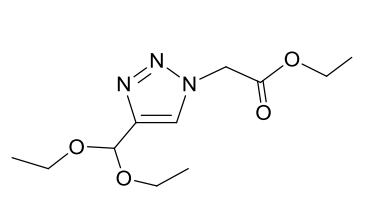

1-Ethoxycarbonylmethyl-4-diethoxymethyl-1,2,3-triazole $\quad(3 \mathrm{bb})^{7}$ : Prepared from $72 \mu \mathrm{L}(0.50 \mathrm{mmol})$ of propiolaldehyde diethyl acetal and $71 \mathrm{mg}(0.55 \mathrm{mmol})$ of ethyl azidoacetate. The product was obtained as a yellow oil (85 mg, 66\%). FTIR: $v$ 3136, 2987, 2883, 1750, 1218, 1064, 1048, 1023. ${ }^{1} \mathrm{H}$ NMR (300 MHz, $\left.\mathrm{CDCl}_{3}\right): \delta 1.12-1.22(\mathrm{~m}, 9 \mathrm{H}), 3.57(2 \mathrm{q}, J=6.9 \mathrm{~Hz}$, $4 \mathrm{H}), 4.51(\mathrm{q}, J=7.2 \mathrm{~Hz}, 2 \mathrm{H}), 5.15(\mathrm{~s}, 2 \mathrm{H}), 5.75(\mathrm{~s}, 1 \mathrm{H}), 7.73(\mathrm{~s}, 1 \mathrm{H}) .{ }^{13} \mathrm{C}$ NMR $(75.5 \mathrm{MHz}$, $\left.\mathrm{CDCl}_{3}\right): \delta 14.4,15.5,51.2,61.8,62.7,97.0,124.0,148.1,166.2$. LC-MS : ELSD pur. 100\%, UV pur. 100\%; $\mathrm{R}_{\mathrm{t}}=5.33 \mathrm{~min} ; \mathrm{m} / z: 230\left(\left[\mathrm{M}+\mathrm{H}-\left(\mathrm{CH}_{2} \mathrm{CH}_{2}\right)\right]^{+}, 80 \%\right), 280\left([\mathrm{M}+\mathrm{Na}]^{+}, 20 \%\right)$.

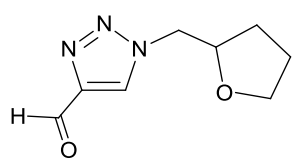

1-((tetrahydrofuran-2-yl)methyl)-1H-1,2,3-triazole-4-carbaldehyde (3bd): Prepared from $72 \mu \mathrm{L}(0.50 \mathrm{mmol})$ of propiolaldehyde diethyl acetal and $69 \mathrm{mg}(0.55 \mathrm{mmol})$ of 2-(azidomethyl)-tetrahydrofurane. The product was obtained as a yellow oil (71mg, 56\%). FTIR: $v 3130,2952,2864,1529,1248,1040 .{ }^{1} \mathrm{H}$ NMR (250 MHz, $\left.\mathrm{CD}_{3} \mathrm{CN}\right): \delta 1.6(\mathrm{~m}, 1 \mathrm{H}), 1.7(\mathrm{~m}, 1 \mathrm{H}), 1.8(\mathrm{~m}, 1 \mathrm{H}), 2.1(\mathrm{~m}, 1 \mathrm{H}), 3.7(\mathrm{~m}, 1 \mathrm{H})$, $3.8(\mathrm{~m}, 1 \mathrm{H}), 4.2(\mathrm{~m}, 1 \mathrm{H}), 4.4(\mathrm{~m}, 1 \mathrm{H}), 4.5(\mathrm{~m}, 1 \mathrm{H}), 8.4(\mathrm{~s}, 1 \mathrm{H}), 10(\mathrm{~s}, 1 \mathrm{H}) .{ }^{13} \mathrm{C} \mathrm{NMR}(62.5$ $\left.\mathrm{MHz}, \mathrm{CD}_{3} \mathrm{CN}\right): \delta$ 26.2, 29.2, 54.8, 68.9, 77.7, 128.7, 148.0, 185.7. HRMS: Calcd for $\mathrm{C}_{8} \mathrm{H}_{12} \mathrm{~N}_{3} \mathrm{O}_{2}$ : 182.0930. Found: 182.0930 .

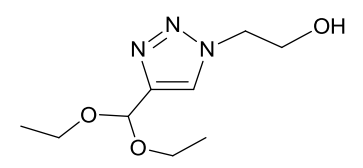

2-(4-(Diethoxymethyl)-1,2,3-triazol-1-yl)ethanol (3be) ${ }^{\mathbf{8}}$ : Prepared from $72 \mu \mathrm{L}(0.50 \mathrm{mmol})$ of propiolaldehyde diethyl acetal and $47 \mathrm{mg}$ $(0.55 \mathrm{mmol})$ of 2 -azidoethanol. The product was obtained as a yellow

\footnotetext{
${ }^{7}$ C. Girard, E. Önen, M. Aufort, S. Beauvière, E. Samson, and J. Herscovici Org. Lett., 2006, 8, 1689-1692

${ }^{8}$ I. Lee, Y. S. Choe, J. Y. Choi, K.-H. Lee, B.-T. Kim, J. Med. Chem. 2012, 55, 883-892
} 
oil (37 mg, 35\%). FTIR: $v$ 3365, 3133, 2877, 1691, 1531, 1040. ${ }^{1} \mathrm{H}$ NMR (250 MHz, $\left.\mathrm{CDCl}_{3}\right)$ : $\delta 1.20(\mathrm{t}, J=7.5,6 \mathrm{H}), 2.24(\mathrm{bs}, 1 \mathrm{H}), 3.75(\mathrm{q}, J=7.5,4 \mathrm{H}), 4.11-4.08(\mathrm{~m}, 2 \mathrm{H}), 4.60-4.57(\mathrm{~m}$, $2 \mathrm{H}), 5.70(\mathrm{~s}, 1 \mathrm{H}), 7.75(\mathrm{~s}, 1 \mathrm{H})$.

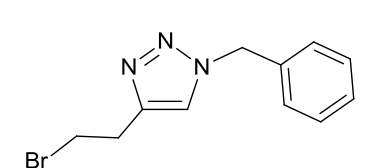

1-Benzyl-4-(2-bromoethyl)-1,2,3-triazole (3ca) ${ }^{\mathbf{9}}$ : Prepared from 47 $\mu \mathrm{L}(0.50 \mathrm{mmol})$ of 4-bromo-1-butyne and $73 \mathrm{mg}(0.55 \mathrm{mmol})$ of benzyl azide. The product was obtained as a white solid $(88 \mathrm{mg}, 67 \%) . \mathrm{mp}=$ $79^{\circ}$ C. FTIR: $v$ 3130, 3067, 3032, 2952, 2921, 1455, 1449, 1438, 1262, 1215, 1205, 1127, 1051, 815, 723, 696. ${ }^{1} \mathrm{H}$ NMR $\left(300 \mathrm{MHz}, \mathrm{CDCl}_{3}\right): \delta 3.24(\mathrm{t}, J=6.8 \mathrm{~Hz}, 2 \mathrm{H}), 3.61(\mathrm{t}, J=6.8$ $\mathrm{Hz}, 2 \mathrm{H}), 5-49(\mathrm{~s}, 2 \mathrm{H}), 7.26-7.21(\mathrm{~m}, 2 \mathrm{H})$ and 7.38-7.31 (m, 4H). ${ }^{13} \mathrm{C}$ NMR $(75.5 \mathrm{MHz}$, $\left.\mathrm{CDCl}_{3}\right):$ 29.4, 31.4, 54.0, 145.2, 121.6, 127.9, 128.6, 129.0, 134.6. LC-MS: ELSD pur. 100\%, UV pur. $\left.100 \% ; \mathrm{R}_{\mathrm{t}}=6.39 \mathrm{~min} ; \mathrm{m} / z: 266([\mathrm{M}+\mathrm{H})]^{+}, 90 \%\right)$,



Ethyl 2-(4-(2-bromoethyl)-1,2,3-triazol-1-yl)acetate (3cb): Prepared from $47 \mu \mathrm{L}(0.50 \mathrm{mmol})$ of 4-bromobut-1-yne and $71 \mathrm{mg}(0.55 \mathrm{mmol})$ of ethyl azidoacetate. The product was obtained as a white solid (93 $\mathrm{mg}, 72 \%) . \mathrm{mp}=64^{\circ} \mathrm{C}$. FTIR: $v 3130,2984,1737,1550,1204 .{ }^{1} \mathrm{H}$ NMR $\left(400 \mathrm{MHz}, \mathrm{CDCl}_{3}\right)$ : $\delta 1.24(\mathrm{t}, J=7.5 \mathrm{~Hz}, 3 \mathrm{H}), 3.33(\mathrm{t}, J=6.9 \mathrm{~Hz}, 2 \mathrm{H}), 3.6(\mathrm{t}, J=6.9 \mathrm{~Hz}, 2 \mathrm{H}), 4.2(\mathrm{q}, J=7.5 \mathrm{~Hz}$, $2 \mathrm{H}), 5.1(\mathrm{~s}, 2 \mathrm{H}), 7.5(\mathrm{~s}, 1 \mathrm{H}) \mathrm{ppm} .{ }^{13} \mathrm{C} \mathrm{NMR}\left(400 \mathrm{MHz}, \mathrm{CDCl}_{3}\right): 14.0,29.3,31.4,50.8,62.4$, 123.2, 145.2, 166.3. LC-MS : ELSD pur. $100 \%$, UV pur. $100 \% ; \mathrm{R}_{\mathrm{t}}=5.56 \mathrm{~min} ; \mathrm{m} / \mathrm{z}: 262$ $\left.([\mathrm{M}+\mathrm{H})]^{+}, 90 \%\right)$. HRMS: Calcd for $\mathrm{C}_{8} \mathrm{H}_{13} \mathrm{BrN}_{3} \mathrm{O}_{2}: 262.0191$. Found: 262.0200 .

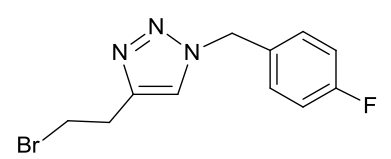

1-(4-Fluorobenzyl)-4-(2-bromoethyl)-1,2,3-triazole

(3cc):

Prepared from $72 \mu \mathrm{L}(0.50 \mathrm{mmol})$ of 4-bromobut-1-yne and $83 \mathrm{mg}$ $(0.55 \mathrm{mmol})$ of 4 -fluorobenzylazide. The product was obtained as a beige solid (117 mg, 82\%). mp: 80-82 ${ }^{\circ} \mathrm{C}$. FTIR: $v 3132,2950,1553,1217,1052 .{ }^{1} \mathrm{H}$ NMR $\left(400 \mathrm{MHz}, \mathrm{CDCl}_{3}\right): \delta 3.22(\mathrm{~m}, 2 \mathrm{H}), 3.58(\mathrm{~m}, 2 \mathrm{H}), 5.43(\mathrm{~s}, 2 \mathrm{H}), 7.20-6.98(\mathrm{~m}, 4 \mathrm{H}), 7.54(\mathrm{~s}$, 1H). ${ }^{1} \mathrm{H}$ NMR (400 MHz, $\left.\mathrm{CDCl}_{3}\right): \delta 29.4,31.4,53.3,116.0,121.5,129.8,130.5,145.3,161.5$, $164.0 \mathrm{ppm}$.

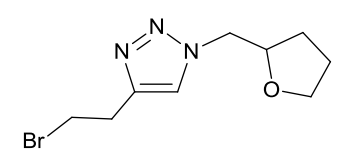

4-(2-bromoethyl)-1-((tetrahydrofuran-2-yl)methyl)-1,2,3-triazole (3cd): Prepared from $72 \mu \mathrm{L}(0.50 \mathrm{mmol})$ of 4-bromobut-1-yne and 69 $\mathrm{mg}(0.55 \mathrm{mmol})$ of 2-(azidomethyl)tetrahydrofurane. The product was obtained as a yellow oil (73 mg, 57\%). FTIR: v3409, 2942, 2807, 1551, 1380, 1219, 1056. ${ }^{1} \mathrm{H}-\mathrm{NMR}\left(250 \mathrm{MHz}, \mathrm{CDCl}_{3}\right): \delta 2.04-1.63(\mathrm{~m}, 4 \mathrm{H}), 3.30-3.19(\mathrm{~m}, 2 \mathrm{H}), 3.61-3.19(\mathrm{~m}, 2 \mathrm{H})$,

\footnotetext{
${ }^{9}$ V. Fiandanese, F. Iannone, G. Marchese, A. Punzi Tetrahedron 2011, 67, 5254-5260
} 
3.40-3.89 (m, 4H), 4.64-4.30 (m, 3H), 5.52-4.29 (m, 3H) and 8.19 (s, 1H) ppm. HRMS (ESI) :Calcd for $\mathrm{C}_{9} \mathrm{H}_{15} \mathrm{BrN}_{3} \mathrm{O}(\mathrm{M}+\mathrm{H}): 260.0398$. Found: 260.0407 .

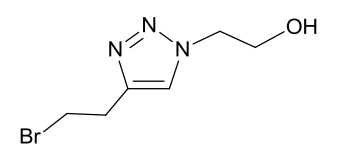

2-(4-(2-bromoethyl)-1,2,3-triazol-1-yl)ethanol (3ce): Prepared from 72 $\mu \mathrm{L}(0.50 \mathrm{mmol})$ of 4-bromobut-1-yne and $47 \mathrm{mg}(0.55 \mathrm{mmol})$ of 2 azidoethanol. The product was obtained as a yellow oil (40 $\mathrm{mg}, 52 \%$ ). FTIR: $v$ 3308, 2930, 1424, 1262, 1055. ${ }^{1} \mathrm{H}-\mathrm{NMR}\left(250 \mathrm{MHz}, \mathrm{CD}_{3} \mathrm{CN}\right): \delta 3.12(\mathrm{t}, J=7.1 \mathrm{~Hz}$, $2 \mathrm{H}), 3.20(\mathrm{Br} \mathrm{s}, \mathrm{OH}), 3.57(\mathrm{t}, J=7.1 \mathrm{~Hz}, 2 \mathrm{H}), 3.75(\mathrm{t}, J=7.1 \mathrm{~Hz}, 2 \mathrm{H}), 4.28(\mathrm{t}, J=7.1 \mathrm{~Hz}$, $2 \mathrm{H})$ and $7.59(\mathrm{~s}, 1 \mathrm{H}) .{ }^{13} \mathrm{C}-\mathrm{NMR}\left(62.5 \mathrm{MHz}, \mathrm{CD}_{3} \mathrm{CN}\right): \delta 30.1,32.9,53.4,61.3,124.1,143.0$ ppm. HRMS: Calcd for $\mathrm{C}_{7} \mathrm{H}_{11} \mathrm{BrN}_{3} \mathrm{O}: 220.0085$. Found: 220.0085.



1-(Benzyltriazol-4-yl)methanol (3da) ${ }^{7}$ : Prepared from $28 \mathrm{mg}(0.50$ mmol) of propargyl alcohol and $73 \mathrm{mg}(0.55 \mathrm{mmol})$ of benzylazide. The product was obtained as a white solid $(64 \mathrm{mg}, 68 \%) . \mathrm{mp}: 76-78^{\circ} \mathrm{C}$. FTIR: $v$ 3257, 3144, 3091, 2953, 2920, 1451, 1048. ${ }^{1} \mathrm{H}-\mathrm{NMR}\left(300 \mathrm{MHz}, \mathrm{CDCl}_{3}\right): \delta 4.11(\mathrm{~s}$, $1 \mathrm{H}), 4.78(\mathrm{~s}, 2 \mathrm{H}), 5.49(\mathrm{~s}, 2 \mathrm{H}), 7.30(\mathrm{~m}, 5 \mathrm{H}), 7.50(\mathrm{~s}, 1 \mathrm{H}) .{ }^{13} \mathrm{C}-\mathrm{NMR}\left(75.5 \mathrm{MHz}, \mathrm{CDCl}_{3}\right): \delta$ 54.1, 56.0, 122.0, 128.1, 128.7, 129.1, 134.5, 148.0. LC-MS : ELSD pur. 97\%, UV pur. $100 \% ; \mathrm{R}_{\mathrm{t}}=3.41 \mathrm{~min} ; \mathrm{m} / z: 190\left([\mathrm{M}+\mathrm{H}]^{+}\right)$.

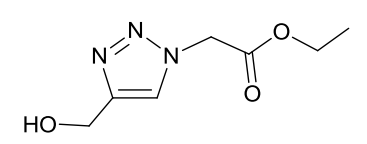

Ethyl 2-[4-(hydroxymethyl)triazol-1-yl]acetate $\quad(3 \mathrm{db})^{\mathbf{7}}$ : $\quad$ Prepared from $28 \mathrm{mg}(0.50 \mathrm{mmol})$ of propargyl alcohol and $71 \mathrm{mg}(0.55 \mathrm{mmol})$ of ethyl azidoacetate. The product was obtained as a pale yellow oily solid (60 mg, $65 \%$ ). FTIR: $v$ 3110, 3076, 3038, 2849, 1708, 1210, 1023. ${ }^{1} \mathrm{H}-\mathrm{NMR}(300 \mathrm{MHz}$, $\left.\mathrm{CDCl}_{3}\right): \delta 1.26(\mathrm{t}, J=7.2 \mathrm{~Hz}, 3 \mathrm{H}), 4.21(\mathrm{q}, J=7.2 \mathrm{~Hz}, 2 \mathrm{H}), 4.72(\mathrm{~s}, 2 \mathrm{H}), 5.12(\mathrm{~s}, 2 \mathrm{H}), 7.67$ (s, 1H). ${ }^{13} \mathrm{C}-\mathrm{NMR}\left(75.5 \mathrm{MHz}, \mathrm{CDCl}_{3}\right): \delta 14.0,50.8,56.1,62.4,123.8,148.3,166.5$. LC-MS: ELSD pur. $99 \%$, UV pur. $100 \% ; \mathrm{R}_{\mathrm{t}}=3.02 \mathrm{~min} ; \mathrm{m} / z: 186\left([\mathrm{M}+\mathrm{H}]^{+}\right), 208([\mathrm{M}+\mathrm{Na}])^{+}$.

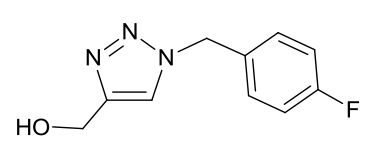

(1-(4-Fluorobenzyl)-1,2,3-triazol-4-yl)methanol (3dc) ${ }^{10}$ : Prepared from $28 \mathrm{mg}(0.50 \mathrm{mmol})$ of propargyl alcohol and $83 \mathrm{mg}(0.55 \mathrm{mmol})$ of 4-fluorobenzylazide. The product was obtained as a yellow oil (74 mg, 72\%). ${ }^{1} \mathrm{H}-\mathrm{NMR}\left(250 \mathrm{MHz}, \mathrm{CDCl}_{3}\right): \delta 2.72(\mathrm{~m}, 2 \mathrm{H}), 5.06$ (bs, $\left.1 \mathrm{H}\right), 5.47$ (s, 2H), 7.23-7.02 $(\mathrm{m}, 4 \mathrm{H}), 7.54(\mathrm{~s}, 1 \mathrm{H})$.

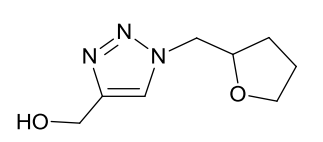

(1-((Tetrahydrofuran-2-yl)methyl)-1,2,3-triazol-4-yl)methanol (3dd): Prepared from $28 \mathrm{mg}(0.50 \mathrm{mmol})$ of propargyl alcohol and $69 \mathrm{mg}(0.55$

\footnotetext{
${ }^{10}$ B. R. Buckley, S. E. Dann, H. Heaney, E. C. Stubbs Eur. J.Org. Chem. 2011, 4, 770-776
} 
mmol) of 2-(azidomethyl)tetrahydrofurane. The product was obtained as a yellow oil (42 $\mathrm{mg}$, 46\%). FTIR: $v 3357,2923,2871,1559,1224,1049 .{ }^{1} \mathrm{H}-\mathrm{NMR}\left(250 \mathrm{MHz}, \mathrm{CDCl}_{3}\right): \delta 2.04-1.63$ (m, 4H), $3.33(\mathrm{bs}, 1 \mathrm{H}), 3.82-3.73(\mathrm{~m}, 2 \mathrm{H}), 4.60-4.26(\mathrm{~m}, 3 \mathrm{H}), 5.52-4.29(\mathrm{~m}, 2 \mathrm{H}), 8.53(\mathrm{~s}, 1 \mathrm{H})$ ppm. HRMS (ESI): Calcd. for $\mathrm{C}_{8} \mathrm{H}_{14} \mathrm{~N}_{3} \mathrm{O}_{2}(\mathrm{M}+\mathrm{H})$ : 184.1086. Found: 184.1092.

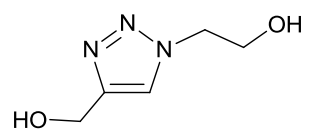

2-(4-(Hydroxymethyl)-1,2,3-triazol-1-yl)ethanol (3de) ${ }^{11}$ : Prepared from $28 \mathrm{mg}(0.50 \mathrm{mmol})$ of propargyl alcohol and $47 \mathrm{mg}(0.55 \mathrm{mmol})$ of 2azidoethanol. The product was obtained as a yellow oil (19 $\mathrm{mg}, 26 \%)$. FTIR: $v 3276,2876,1558,1430,1358,1232,11136,1045,1007 .{ }^{1} \mathrm{H}-\mathrm{NMR}(250 \mathrm{MHz}$, $\left.\mathrm{CDCl}_{3}\right): \delta 1.89(\mathrm{bs}, 1 \mathrm{H}), 3.80(\mathrm{bs}, 1 \mathrm{H}), 4.08(\mathrm{t}, J=7.5,2 \mathrm{H}), 4.49(\mathrm{t}, J=7.5,2 \mathrm{H}), 4.78(\mathrm{~s}$, 2H), $7.66(\mathrm{~s}, 1 \mathrm{H})$.

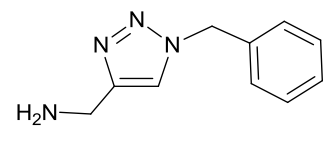

(1-Benzyl-1,2,3-triazol-4-yl)methanamine (3ea) ${ }^{\mathbf{1 2}}$ : Prepared from 23 $\mathrm{mg}(0.50 \mathrm{mmol})$ of propargylamine and $73 \mathrm{mg}(0.55 \mathrm{mmol})$ of benzylazide. The product was obtained as a white solid (16 $\mathrm{mg}, 17 \%)$. ${ }^{1} \mathrm{H}-\mathrm{NMR}\left(250 \mathrm{MHz}, \mathrm{CDCl}_{3}\right): \delta 2.18$ (bs, 2H), 4.29 (s, 2H), 5.49 (s, 2H), 7.30 (m, $\left.5 \mathrm{H}\right), 7.88$ $(\mathrm{s}, 1 \mathrm{H})$.

\section{General procedure for catalyst recycling}

To a screw-capped vial were successively added ethyl propiolate $(50 \mu \mathrm{L} ; 0.49 \mathrm{mmol})$, benzyl azide (73.2 mg; 1.15 eq.), dichloromethane ( $2 \mathrm{~mL}$ ) and finally the $\mathrm{Cu}$ (II)-SBA 15 (25 $\mathrm{mg} ; 7.5 \% \mathrm{Cu} w / \mathrm{w} ; 6 \mathrm{~mol} \%)$. The reaction was stirred overnight and the catalyst was recovered by filtration over a nylon membrane $\left(0.45 \mu \mathrm{m}\right.$, Millipore $\left.{ }^{\circledR}\right)$ and washed with dichloromethane $(2 \times 2 \mathrm{~mL})$. The combined organic solvent was evaporated under vacuo yielding the desired triazole $(97-110 \mathrm{mg} ; 87-97 \%)$. After the $5^{\text {th }}$ run we recovered $23.9 \mathrm{mg}$ of the catalyst (over the $25 \mathrm{mg}$ used for the $1^{\text {st }}$ reaction), hence a recovery of $93 \%$ over 5 runs (99\% average recovery per run).

\footnotetext{
${ }^{11}$ Y.-L. Zhao, W. R. Dichtel, A. Trabolsi, S. Saha, I. Aprahamian, J. Fraser Stoddart, J. Am. Chem. Soc. 2008, 130, 11294 11296

${ }^{12}$ H.A. Orgueira, D. Fokas, Y. Isome, P. C.-M. Chan and C. M. Baldino Tetrahedron Lett. 2005, 46, 2911-2914
} 

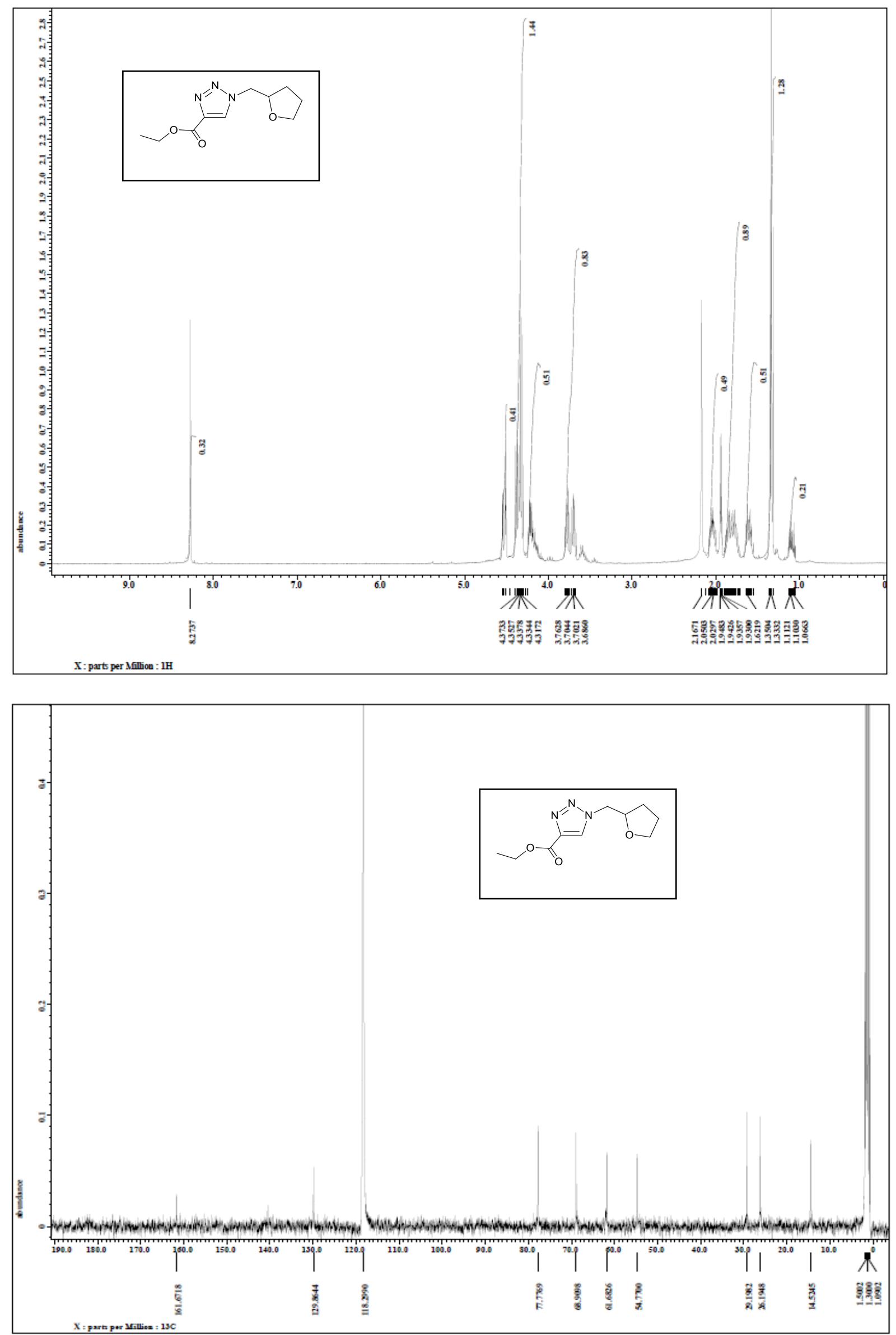

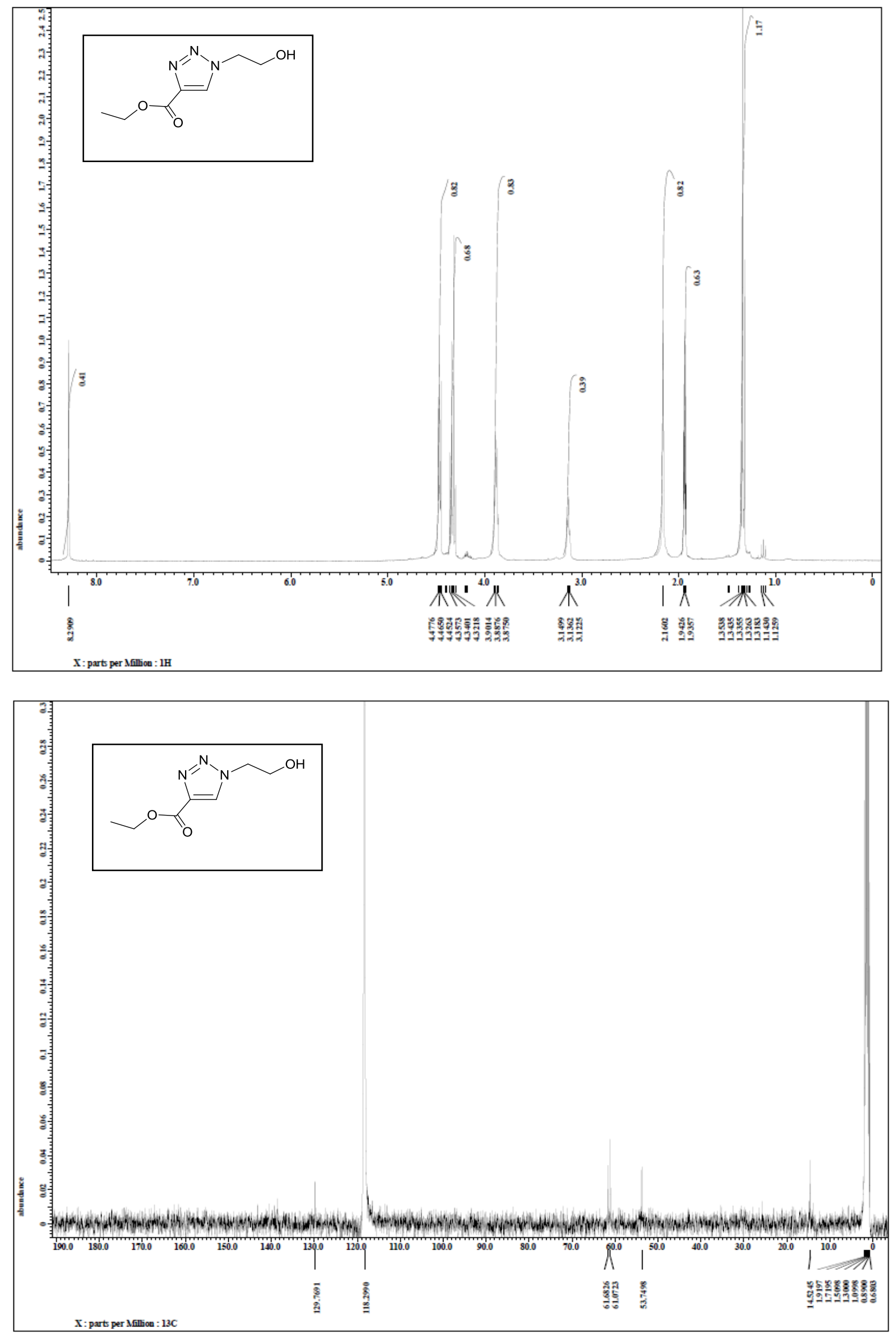

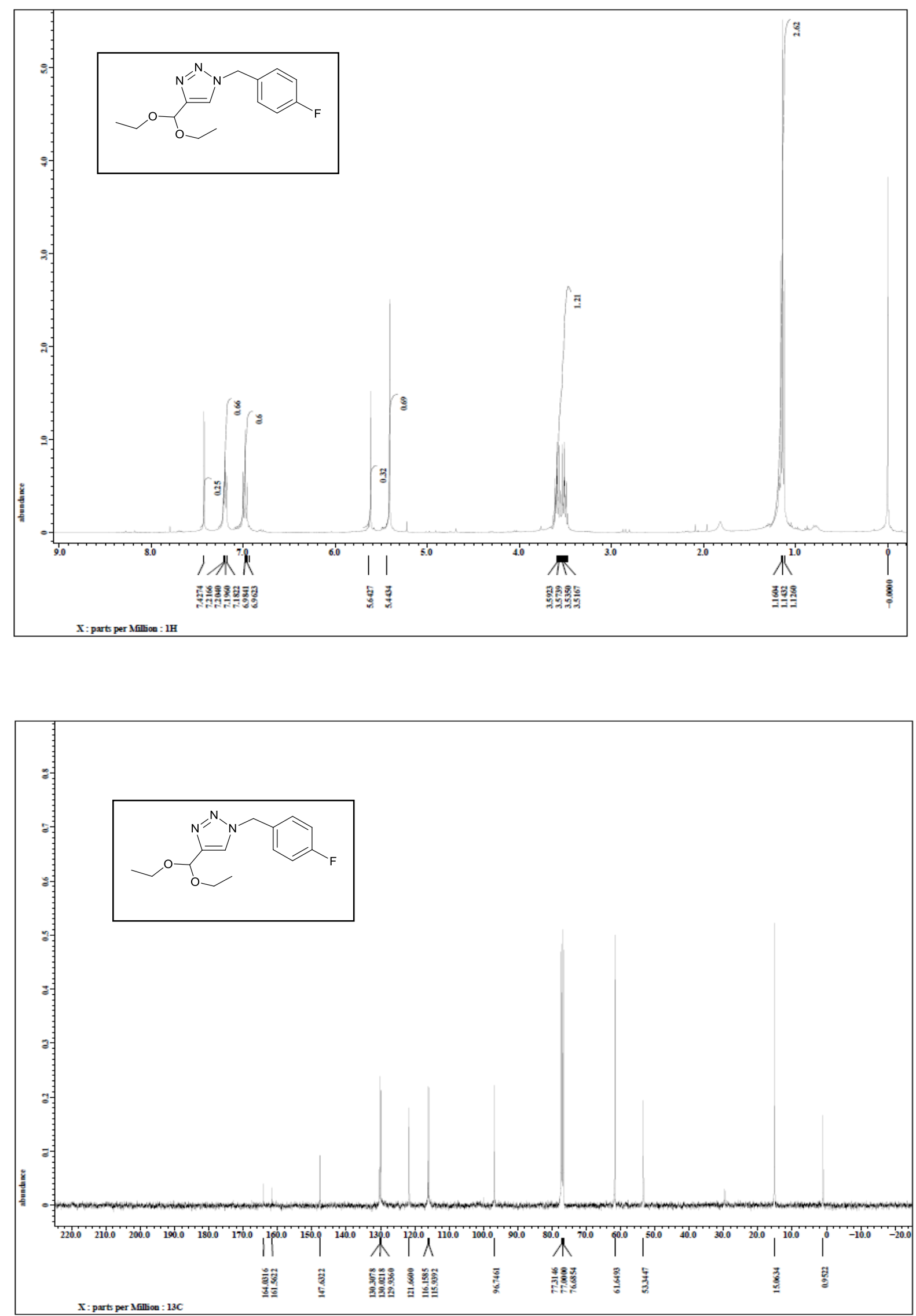

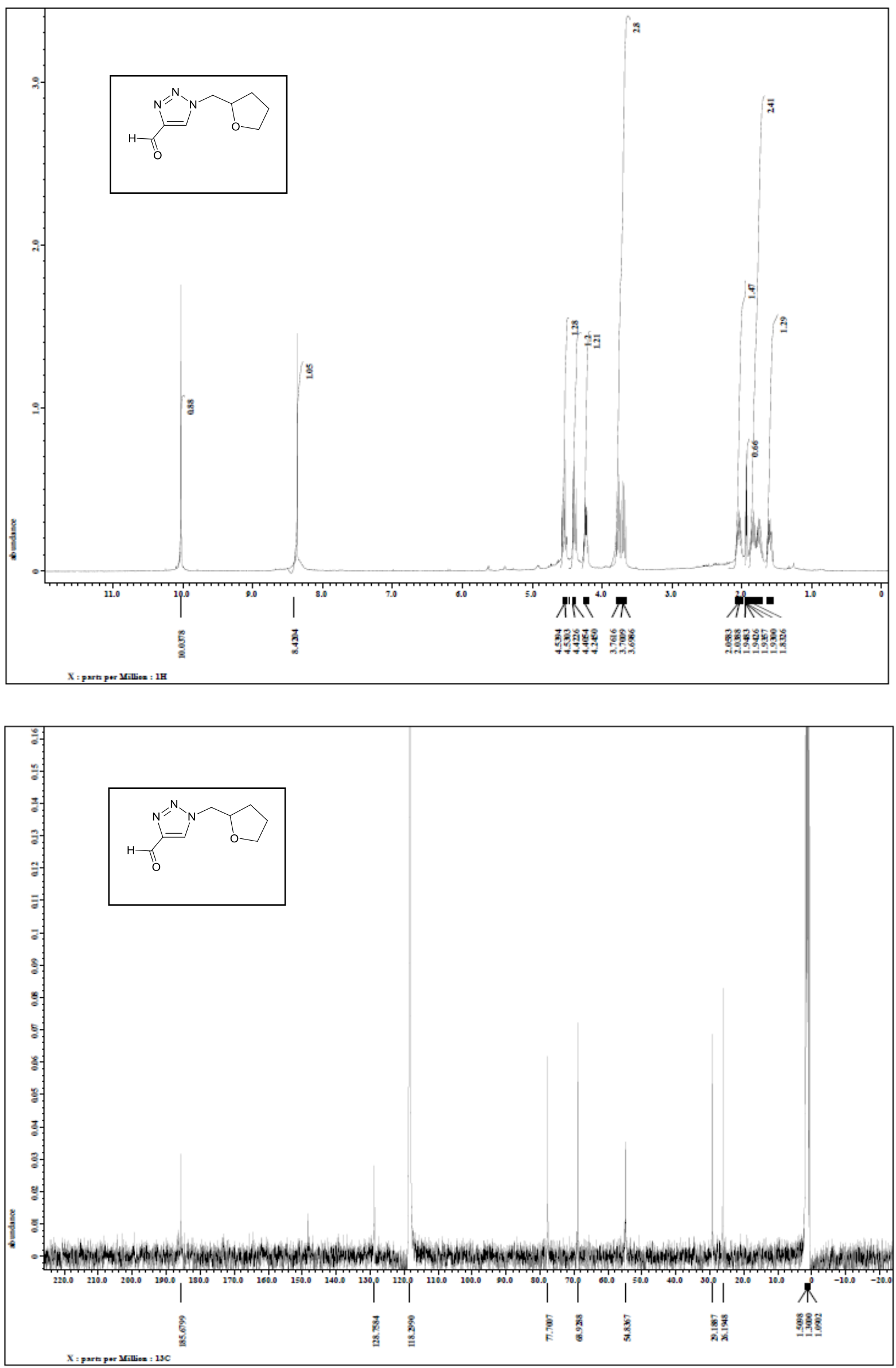



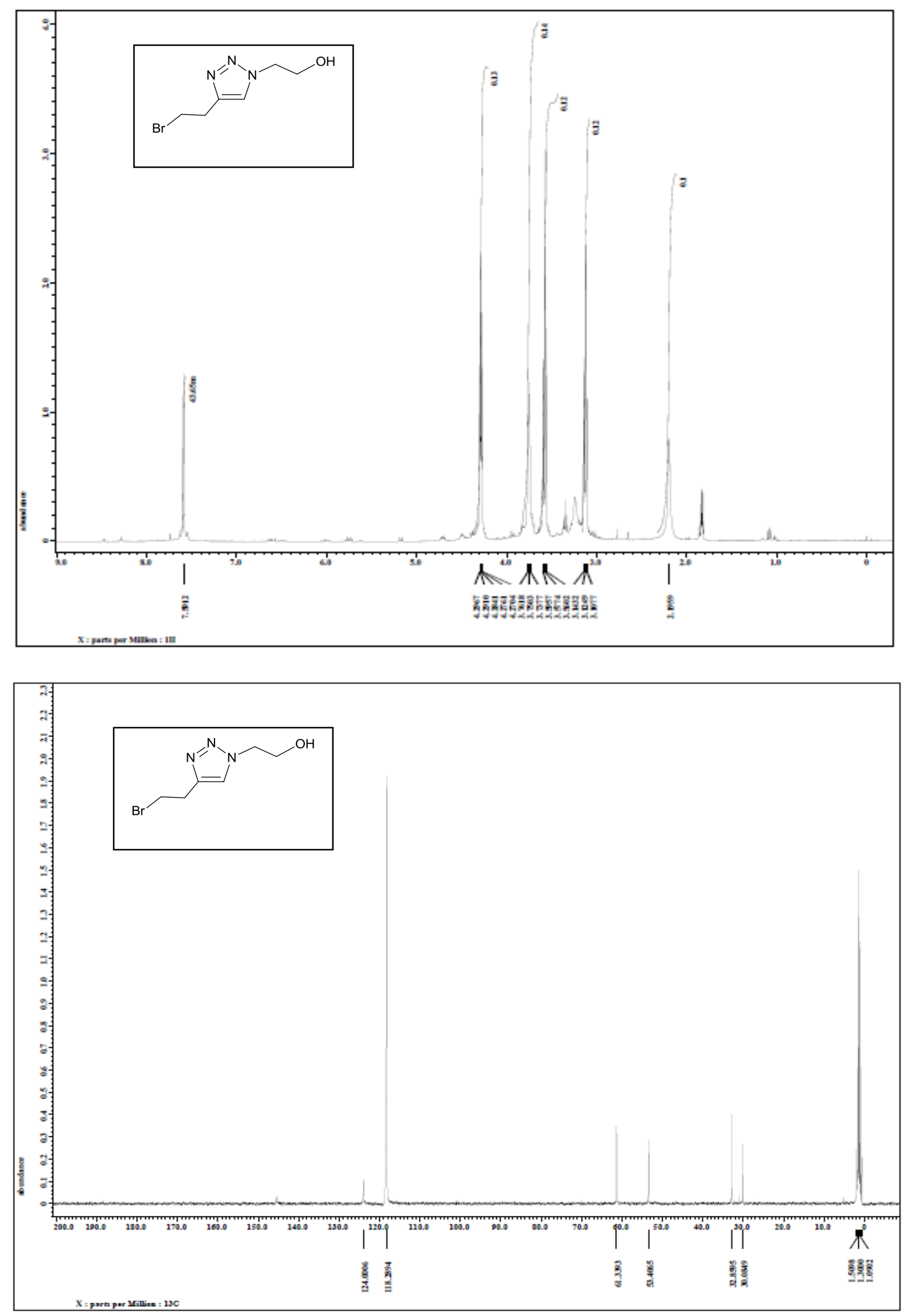

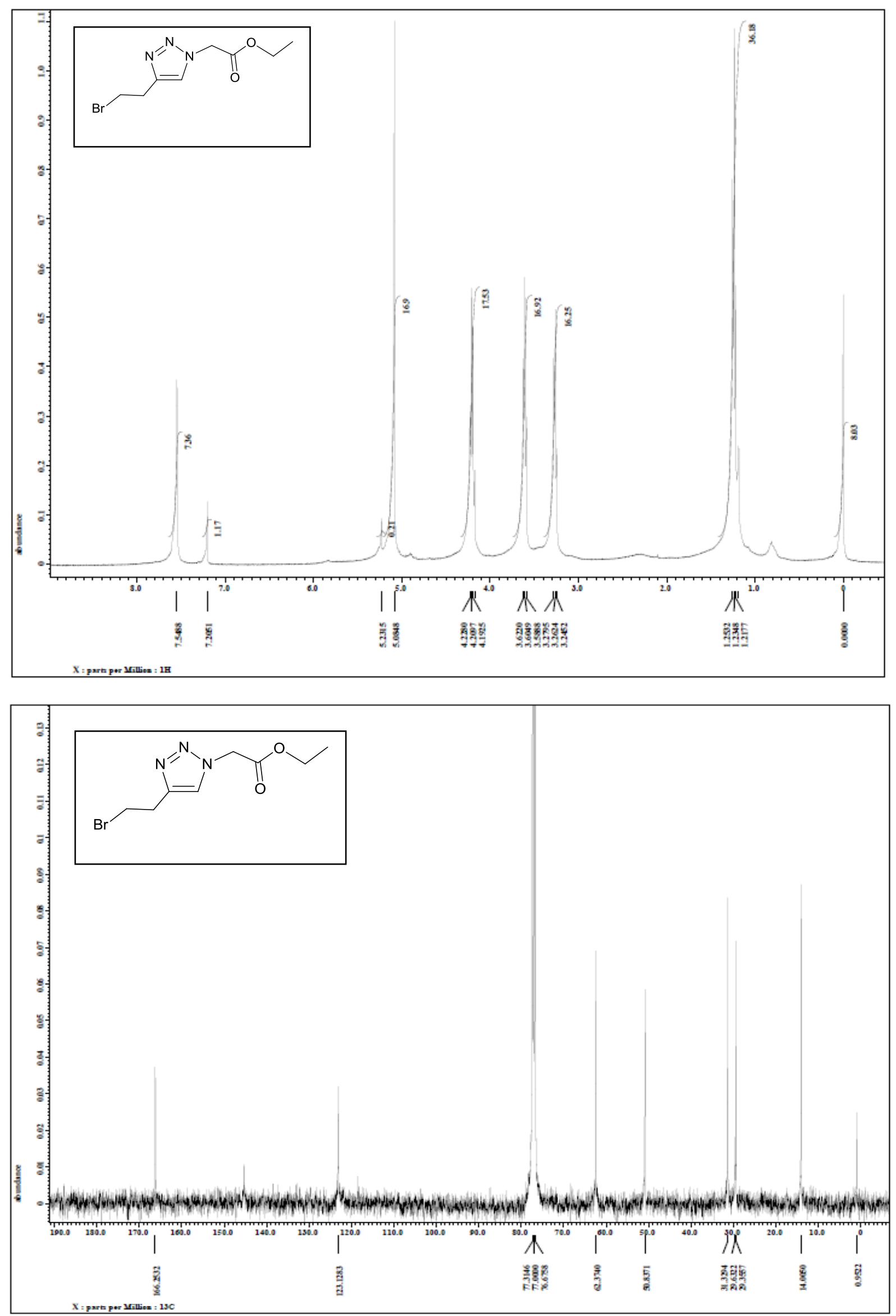